\title{
Discrimination of Heavy Metal Sources in the Sefidrud Delta Coastal Lagoons, Caspian Sea, N Iran: A Statistical Approach
}

Behrouz Rafiei ( $\nabla$ b_rafiei@basu.ac.ir)

Bu-Ali Sina University: Bu Ali Sina University https://orcid.org/0000-0002-5384-7462

Fatemeh Ahmadi-Ghomi

Bu-Ali Sina University: Bu Ali Sina University

Asghar Seif

Bu-Ali Sina University: Bu Ali Sina University

Ali Shakibaazad

GSI: Geological Survey and Mineral Exploration of Iran

Sonia Shamshiri

Bu-Ali Sina University: Bu Ali Sina University

Zahra Sharifi-Abzahli

Bu-Ali Sina University: Bu Ali Sina University

\section{Research Article}

Keywords: Metal contamination, statistical analysis, anthropogenic source, Sefidrud Delta, Coastal lagoon, Caspian Sea

Posted Date: October 14th, 2021

DOI: https://doi.org/10.21203/rs.3.rs-924042/v1

License: (c) (i) This work is licensed under a Creative Commons Attribution 4.0 International License. Read Full License 


\section{Abstract}

29 Amirkola (more than 500 years in age), Kiashahr and Zibakenar (a few decades in age) lagoons 30 are located on the Sefidrud Delta, the southern coast of the Caspian Sea. Evaluating the 31 pollution degree caused by heavy metals (including $\mathrm{Cu}, \mathrm{Cr}, \mathrm{Co}, \mathrm{Ni}, \mathrm{Pb}, \mathrm{Zn}$ and $\mathrm{V}$ ), 106 32 sediment samples and three sediment cores were taken from studied lagoons. Three indices, 33 including geo-accumulation index ( $\left.\mathrm{I}_{\mathrm{geo}}\right)$, contamination factor $(\mathrm{CF})$, and pollution load index 34 (PLI), were employed to determine the contamination degree in the lagoons. Based on contamination indices, the Kiashahr and Zibakenar lagoons show significant to moderate contamination with $\mathrm{Co}, \mathrm{Cu}, \mathrm{Pb}, \mathrm{Zn}$ and $\mathrm{V}$. Nonparametric statistical analysis (Two-step cluster analysis, analysis of variance, and T-test technique) was used to discriminate the pollution sources. Statistical methods indicated the unique interpretation of contaminants sources. There is a significant difference in metal concentrations between Amirkola and two younger lagoons. Despite the same geogenic origin of sediments in the Sefidrud Delta and lagoons deposits, Co, $\mathrm{Zn}$, and $\mathrm{Pb}$ show anthropogenic sources in the newly-formed Kiashahr and Zibakenar lagoons.

42 Keywords: Metal contamination, statistical analysis, anthropogenic source, Sefidrud Delta, 43 Coastal lagoon, Caspian Sea

\section{Introduction}

River deltas and their related coastal lagoons are influenced mainly by human activities (e.g.

47 urbanization, industries, agriculture, river damming, fisheries, navigation and harbour 48 activities) in the catchment areas and coasts. The continuous changes in morphology and 49 increasing sediment pollution cause deltaic regions to be frequently evaluated in order to 50 protect these areas. Coastal lagoons are shallow back-barrier water bodies, usually extended 51 along the coastline, detached by a barrier from the sea (Kjerfve, 1994). Coastal lagoons play 52 an important role in flood control and coastline stability, aquaculture and tourism activities. 
53 These areas act as sediment traps and contain sediments and other materials derived from source area lithology, agricultural, urban and industrial activities (Etemadi Deilami et al., 2010; Kazanc1 et al., 2004). Heavy metals, as one of the environmental pollutants, can accumulate in lagoon bed sediments. Several studies have been conducted on the accumulation of these metals in coastal lagoons in different regions of the world (e.g., Chen et al., 2010; Uluturhan et al., 2011; Wang et al., 2015; García and Muñoz-Vera, 2015; Beraldi et al., 2019; OntiverosCuadras et al., 2019; Zonta et al., 2019; Romano et al., 2021).

The Sefidrud River, with a length of more than $820 \mathrm{~km}$, originates from the Zagros Mountains and enters the Caspian Sea after joining small rivers originated from the Alborz Mountains. The largest delta of the southern coast of the Caspian Sea has been formed by this river over the past 2 million years. The Sefidrud Delta was formed during Pleistocene (Annels et al., 1975) and developed based on tectonic, sea-level changes and gradual regression of the Caspian Sea (Kazancı et al., 2004; Jedari Eivazi et al., 2005; Kazancı and Gulbabazadeh, 2013). During the Caspian Sea regression, some lagoons were formed. Longshore currents (from northwest to southeast) have also significantly impacted coastal morphology and lagoons

68 formation. These currents have driven sediments almost parallel to the coast and gradually create coastal sand spits. These sand spits, along with river and delta sediments, have entirely cut off the connection between the isolated part of the sea and created lagoons (Kousari, 1986; Lahijani et al., 2009; Leroy et al., 2011) such as Amirkola, Zibakenar and Kiashahr lagoons, which were formed during Quaternary.

73 Excessive discharge of urban, industrial and agricultural wastewaters and runoff, which 74 contains various pollutants such as heavy metals, has resulted in the accumulation of this group 75 of pollutants in delta's coastal sediments and shoreface deposits (Rafiei et al., 2017), lagoons 76 on the Sefidrud Delta and the Anzali Lagoon (Rafiei et al., 2012; Vesali Naseh et al., 2012; 77 Rafiei et al., 2015). 
78 The goals of this study were to investigate: 1) the concentration, degree of contamination, and spatial distribution of $\mathrm{Cr}, \mathrm{Cu}, \mathrm{Co}, \mathrm{Ni}, \mathrm{Pb}, \mathrm{Ti}, \mathrm{V}, \mathrm{Zn}$ and $\mathrm{Zr}$ in the surface sediments of Amirkola, Zibakenar, and Kiashahr lagoons; 2) the temporal distribution of mentioned metals in the core samples taken from the three mentioned lagoons, 3) Comparison of heavy metal concentrations and their sources in studied lagoons.

\section{Materials \& Methods}

\subsection{Study Area}

The Sefidrud Delta with an area of $1700 \mathrm{~km}^{2}$ is located in the Gilan Province $\left(37^{\circ} 00^{\prime}-37^{\circ} 27^{\prime}\right.$

$\mathrm{N}$ and $49^{\circ} 28^{\prime}-50^{\circ} 16^{\prime} \mathrm{E}$ ) north of Iran. Strong longshore current and high sediment supply have created coastal lagoons on the Sefidrud Delta. The Amirkola, Kiashahr, and Zibakenar lagoons are the main existing coastal lagoons on this delta (Fig. 1).

90 Among them, the Amirkola Lagoon was created due to the activity of the old Sefidrud and separated from the Caspian Sea about 500 years ago (around 1600 AD) (Jedari Eivazi et al., 2005; Leroy et al., 2011; Kazanc1 and Gulbabazadeh, 2013; Haghani, 2015) and is the oldest. The Amirkola Lagoon, with $12.3 \mathrm{~km}^{2}$, is located between Lahijan, Kiashahr and Langarud

94 cities and has a maximum water depth of 2 meters (Naderi Beni et al., 2013).

95 The Zibakenar and Kiashahr lagoons, located on the new Sefidrud Delta (the currently active delta lobe), were formed due to the last few decades' of displacements (avulsion) of the

97 Sefidrud River on its delta (Sarvar, 2008; Kazanc1 and Gulbabazadeh, 2013; Haghani, 2015). The Kiashahr Lagoon is located in the eastern part of the delta and northeast of Kiashahr. The

99 Zibakenar Lagoon is located in the western part of the delta and the north of Zibakenar city

100 (Fig. 1). The water depth in these lagoons is generally less than $2 \mathrm{~m}$ and is controlled by 101 freshwater entering through precipitation and irrigation.

\subsection{Sampling}


103 A total of 106 surface sediment samples (Amirkola: 56, Zibakenar: 22 and Kiashahr: 28

104 samples) and three core samples (one core sample for each lagoon) were collected from all

105 three lagoons (Fig. 1). Surface samples were taken by Van Veen Grab in a regular network and

106 packed in polyethylene bags. The core samples were taken by PVC pipe and hand auger. Two

107 ends of the tubes were sealed after taking core samples so that their contents remain intact.

108 Samples were sent to Bu-Ali Sina University and Geological Survey of Iran (GSI) laboratories

109 for various physicochemical and chemical analyses.

\section{2.3. Physicochemical Analysis}

111 All samples were dried at room temperature then a part of each sample was used for

112 physicochemical analyses. Particle size analysis was performed on the samples. Twenty

113 percent hydrogen peroxide $\left(\mathrm{H}_{2} \mathrm{O}_{2}\right)$ solution was added to $50 \mathrm{~g}$ of each sample to dissolve the

114 organic matter; then, samples were washed with deionized water. After that, the coarse-grained

115 and fine-grained fractions of samples were separated using the wet sieving method. For

116 granulometry purposes, a column of sieves was used for the coarse- and medium-grained parts

117 (Lewis \& Macconchie, 1994). The fine-grained fraction (under 62.5 microns) was tested by

118 Fritsch A22 Compact particle size analyzer in the sedimentology laboratory of Bu-Ali Sina

119 University.

120 To determine the $\mathrm{pH}$ of samples, $2 \mathrm{~g}$ of dry samples were mixed with $10 \mathrm{ml}$ of deionized water

121 (1:5 sediment to water ratio) and stirred for 2 hours (Segura et al., 2006). The mixture was then

122 let to settle, and the $\mathrm{pH}$ was measured from the clear liquid above the sediments. The titration

123 method was carried out to determine the samples' calcium carbonate content (Carver, 1971).

124 This process was repeated three times to ensure the results. The organic matter amount in 125 sediments was determined by the burning method, for which $1 \mathrm{~g}$ of the air-dried sample was 126 heated at $400^{\circ} \mathrm{C}$ (Heiri et al., 2001) for 4 hours in the oven. The weight difference was related 127 to organic matter amount. 


\subsection{Chemical Analysis}

129 Inductively coupled plasma-optical emission spectrometry (ICP-OES) method was used to

130 determine $\mathrm{Cr}, \mathrm{Cu}, \mathrm{Co}, \mathrm{Ni}, \mathrm{Pb}, \mathrm{Ti}, \mathrm{V}, \mathrm{Zn}$ and $\mathrm{Zr}$ concentrations in the samples. For this purpose,

131 the $<0.0625 \mathrm{~mm}$ fraction of samples were entirely digested by a mixture of four acids:

132 hydrochloric, nitric, fluoric and perchloric. The experiment was performed at the geochemical

133 laboratory of GSI, Iran, using Varian 735.

\section{2.5. Contamination Assessment}

135 Both single and integrated pollution indices were used to evaluate the environmental 136 assessment of $\mathrm{Cr}, \mathrm{Cu}, \mathrm{Co}, \mathrm{Ni}, \mathrm{Pb}, \mathrm{Ti}, \mathrm{V}, \mathrm{Zn}$ and $\mathrm{Zr}$ in the studied lagoons. Geo-accumulation

137 ( $\mathrm{Igeo}_{\mathrm{g}}$ and contamination factor (CF) are single indices, and pollution load index (PLI) is an

138 integrated Index. These approaches are the most common environmental risk assessment 139 methods (Caeiro et al., 2005; Hou et al., 2013).

140 Geo-accumulation Index ( $\mathrm{Igeo}_{\text {geo }}$ can determine the amount of metal pollution in sediments by

141 comparing the concentration of specific metals in samples with the pre-industrial concentration

142 of the same metal in the background (Zhao et al., 2012) and is calculated by the following 143 equation (Müller, 1969):

$$
\mathrm{I}_{\text {geo }}=\log [\mathrm{Cn} / 1.5 \mathrm{Bn}]
$$

145 where $C_{n}$ is the metal concentration (n) in the sediment sample, $B_{n}$ is the geochemical 146 background of the studied metal (n), and coefficient 1.5 has been applied to minimize possible 147 geogenic and anthropogenic effects (Qingjie and Jun, 2008). In this study, background values 148 are the average concentration of metals in the Upper Continental Crust (UCC) (Rudnick and

149 Gao, 2003). The geo-accumulation index is divided into seven categories (Müller, 1981), from

1500 to 6 (Table 1), based on the level and degree of pollution. Class 0 specifies the lack of 151 contamination, whereas class 6 indicates the upper limit of the contamination. The highest class 
1526 reflects 100-fold enrichment of the metals than their background values (Harikumar and 153 Jisha, 2010).

154 Contamination factor $(\mathrm{CF})$ is the ratio of the concentration of each metal $\left(\mathrm{C}_{\mathrm{M}}\right)$ to the 155 background values $\left(\mathrm{C}_{\mathrm{B}}\right)$ :

$$
\mathrm{CF}=\mathrm{CM} / \mathrm{CB}
$$

157 The average concentration of metals in the UCC has been used as the background. The CF 158 categories are presented in Table 1 (Håkanson, 1980). The CF is applied to find the 159 contamination level of metals.

160 The pollution load index (PLI) was performed based on Suresh et al. (2012) To assess the

161 environmental quality of sediments. This index is calculated by the $\mathrm{n}^{\text {th }}$ root resulting from the 162 multiplication of $\mathrm{n}$ pollution index $(\mathrm{CF})$ for a single sediment sample as follows:

$$
\text { PLI for a sample }=(\mathrm{CF} 1 \times \mathrm{CF} 2 \times \ldots \times \mathrm{CFn})^{1 / \mathrm{n}}
$$

164 where $\mathrm{n}$ is the number of sediment samples in each lagoon. The PLI for a lagoon is the $\mathrm{n}^{\text {th }}$ 165 root of the product of $n$ PLI values.

$$
\text { PLI for a lagoon }=(\text { PLI1 } \times \text { PLI2 } \times \ldots \times \text { PLIn })^{1 / n}
$$

167 where $\mathrm{n}$ is the number of lagoons. The PLI values greater than 1 indicate metal contamination,

168 while values less than 1 indicate no contamination (Tomlinson et al., 1980).

\section{$169 \quad 2.6$. Statistical Analysis}

170 Statistical analysis methods are usually used in environmental studies to determine data 171 distribution and correlation among the variables. In this study, SPSS for Windows version 21 172 was used for statistical analysis. Correlation analysis is used to describe the strength and 173 direction of the linear relationship between the studied elements.

174 Cluster analysis (CA) was conducted to categorize samples of different lagoons based on their 175 constituent elements' similarities. In this study, two-step cluster analysis was conducted to 176 identify relatively homogeneous groups of variables, using an algorithm that starts with each 
177 variable in a separate cluster and combines clusters until only one is left. As the variables have 178 significant differences in scaling, standardization was performed before computing 179 proximities, which can be achieved automatically by the hierarchical cluster analysis 180 procedure.

181 One-way analysis of variance (ANOVA) and compare means analysis were used to investigate

182 the differences or similarities between the studied elements in different lagoons. The 183 nonparametric tests, including the Kruskal-Wallis and Mann-Whitney test with Bonferroni 184 adjustment method, were used for pairwise comparison.

185

186 3. Results and Discussion

\section{3.1. Physicochemical Analysis}

188 The granulometric analysis results of Amirkola, Zibakenar, and Kiashahr lagoons are presented

189 in Table 2. Based on granulometry results, the texture of most sediment samples in Amirkola

190 Lagoon is fine to medium grain. The sediment samples were frequently classified as slightly

191 sandy mud to slightly muddy sand (Fig. 2). Some gravelly samples in this lagoon were mostly

192 close to the lagoon's barrier and sea-side. Most samples from Zibakenar and Kiashahr lagoons

193 have fine grain texture, so more than $55 \%$ of samples were classified as mud, sandy mud,

194 slightly gravely mud, and slightly gravely sandy mud based on Folk (1980). Currently, none of

195 these lagoons have major water inlets.

196 The titration results (Table 2) showed that the carbonate contents of the sediment samples are

197 relatively high (mean carbonate content in Amirkola: 54.49\%; Zibakenar: 44.40\%; and

198 Kiashahr: $43.30 \%$ ) and constitute about half of the sediments. The high carbonate content in

199 the samples is mainly due to gastropod and pelecypod (bivalve) shell fragments. Organic matter

200 content in the lagoons is variable. The mean amount of organic matter measured for Amirkola,

201 Zibakenar, and Kiashahr lagoons were 21.01\%, 11.52\%, and 9.96\%, respectively. The higher 
amount of organic matter in Amirkola Lagoon might result from its age and plant growth

203 around it. The mean $\mathrm{pH}$ values measured for Amirkola, Zibakenar and Kiashahr lagoons were $2047.75,7.53$ and 7.58, respectively, indicating neutral to slightly alkaline conditions in all three 205 lagoons.

\section{3.2. Chemical Analysis}

207 Descriptive statistics of some major and minor element concentrations in sediment samples of 208 all three lagoons are displayed in Table 3. Out of 56 samples in the Amirkola Lagoon, the Pb, $209 \mathrm{Ni}$, and Co concentrations were below the detection limit in 40, 33 and 52 samples, 210 respectively. The concentration of $\mathrm{Cu}, \mathrm{Cr}, \mathrm{Co}, \mathrm{Ni}, \mathrm{Pb}, \mathrm{Zn}$ and $\mathrm{V}$ was considered because of 211 their potentially toxic natures. The order of mean metal concentration is $\mathrm{Zn}>\mathrm{Pb}>\mathrm{Ni}>\mathrm{V}>$ $212 \mathrm{Cu}>\mathrm{Cr}>\mathrm{Co}$ for Amirkola Lagoon, $\mathrm{V}>\mathrm{Zn}>\mathrm{Co}>\mathrm{Cu}>\mathrm{Ni}>\mathrm{Pb}>\mathrm{Cr}$ for Zibakenar Lagoon, 213 and $\mathrm{Zn}>\mathrm{V}>\mathrm{Co}>\mathrm{Cu}>\mathrm{Ni}>\mathrm{Pb}>\mathrm{Cr}$ for Kiashahr Lagoon (Table 3). The concentration order 214 of metals in Amirkola Lagoon is different from the two other lagoons. Both Zibakenar and 215 Kiashahr lagoons show almost the same order. Also, the variation of the heavy metals in the 216 Amirkola, Zibakenar and Kiashahr lagoons are demonstrated in Fig. 3. Noticeable differences 217 in metal concentrations and ranges are seen in three lagoons. Differences were studied by 218 comparing the mean values of metals in sediment samples. The mean values of studied metals 219 in the Amirkola Lagoon were considerably lower than the other two (Table 3). Also, major 220 element contents in the Amirkola sediment samples were lower than the other lagoons except 221 for $\mathrm{Ca}$. The higher amount of $\mathrm{Ca}$ in the Amirkola Lagoon comparing to other lagoons is 222 associated with higher $\mathrm{CaCO}_{3}$ content (Table 2) in this lagoon. High $\mathrm{Al}$ content in the 223 Zibakenar and Kiashahr lagoons samples is due to more mud and clay minerals in these 224 lagoons.

225 The highest heavy metal concentrations are observed in Zibakenar and Kiashahr lagoons. The 226 mean concentration values of $\mathrm{Cu}, \mathrm{Co}, \mathrm{Cr}, \mathrm{Ni}, \mathrm{Pb}, \mathrm{V}$ and $\mathrm{Zn}$ in the Zibakenar and Kiashahr 
lagoons are at least two times higher than that of Amirkola Lagoon. The ranges of $\mathrm{Zn}$ and $\mathrm{Pb}$ 228 in the Kiashahr Lagoon are about 450 and $90 \mathrm{mg} / \mathrm{kg}$, respectively, indicating the metals' 229 heterogeneous dispersion in this lagoon. Cobalt $(16.47-239.37 \mathrm{mg} / \mathrm{kg})$ and $\mathrm{V}(19.90-306.27$ $230 \mathrm{mg} / \mathrm{kg}$ ) also show a wide range in Zibakenar Lagoon. The distribution maps of some metals in 231 the Zibakenar and Kiashahr lagoons are shown in Fig. 4. Metals distribution map for the 232 Amirkola Lagoon is not displayed due to the lack of data and/or uniform dispersal of the 233 elements in this lagoon.

234 Therefore, as can be seen, the concentration of potentially toxic metals is much lower in the 235 Amirkola Lagoon comparing to the Zibakenar and Kiashahr lagoons. The last two lagoons have 236 been formed over the past five decades on the new Sefidrud Delta (Sarvar, 2008; Yamani et 237 al., 2013; Haghani, 2015). The Amirkola Lagoon was formed on the old Sefidrud Delta over 238500 years ago (Jedari Eivazi et al., 2005; Leroy et al., 2011; Kazancı and Gulbabazadeh, 2013; 239 Haghani, 2015).

240 A core sample has been taken from each lagoon to investigate the changes in metallic element 241 concentration over time. Sedimentary facies changes and concentrations of heavy metals 242 studied in each core sample are displayed in Fig. 5. The core sample of the Amirkola Lagoon 243 with a depth of $180 \mathrm{~cm}$ is composed of muddy and sandy deposits. Lead, Co, and $\mathrm{Zn}$ increase 244 slightly from the bottom to the top, indicating human activities around the lagoon during past 245 decades. Chromium and V have a negative relationship with mud and a positive relationship 246 with sand amounts. These elements have a geogenic origin. In the Zibakenar Lagoon core 247 sample with a depth of $185 \mathrm{~cm}$, metal elements directly correlate with the amount of mud and 248 show a decrease toward the surface except for $\mathrm{Pb}$ and $\mathrm{Zn}$, which may have an anthropogenic 249 origin. The core sample taken from the Kiashahr Lagoon was about $155 \mathrm{~cm}$, and the whole 250 core is almost composed of mud deposits, so the elements do not show any remarkable changes 251 along with the core depth. Only $\mathrm{Pb}$ and $\mathrm{Zn}$ have been increased at the surface sediments. This 
252 lagoon has an outlet towards the Caspian Sea and Kiashahr harbour, therefore increasing $\mathrm{Pb}$ 253 and $\mathrm{Zn}$ toward the port might be related to human activities.

\section{3.3. Assessment of heavy metal pollution}

255 Descriptive statistics results of the geo-accumulation index $\left(\mathrm{I}_{\text {geo }}\right)$ in the three lagoons sediment 256 samples are presented in Table 4. According to the results, the mean $\mathrm{Igeo}_{\mathrm{g}}$ of $\mathrm{Cr}$ and $\mathrm{Ni}$ in all 257 lagoons is almost similar and does not show any specific changes, so all samples are practically uncontaminated with $\mathrm{Cr}$ and $\mathrm{Ni}$.

259 In general, mean $I_{g e o}$ values of the Amirkola Lagoon samples are classified as practically 260 uncontaminated for all studied metals. Only three samples out of 16 show Igeo values between 2610 and 1 , representing these samples are uncontaminated to moderately contaminated with $\mathrm{Pb}$ 262 in the Amirkola Lagoon.

263 The two other lagoons are moderately contaminated by Co and uncontaminated to moderately

264 contaminated by $\mathrm{Cu}$. The samples of Kiashahr Lagoon are also uncontaminated to moderately 265 contaminated by $\mathrm{Zn}$.

266 Table 5 shows descriptive statistics results of CF and PLI in sediment samples of all three 267 lagoons. Based on the $\mathrm{CF}$ results, all samples are not contaminated with $\mathrm{Cr}$ and $\mathrm{Ni}$. The samples 268 taken from Amirkola Lagoon show CF values less than 1, indicating low contamination with 269 metals except for $\mathrm{Pb}$, whose mean $\mathrm{CF}$ value is 1.43 . The samples are moderately contaminated 270 with $\mathrm{Pb}$ for Amirkola Lagoon sediment samples.

271 Cobalt's mean CF values are 4.86 and 3.92 in Zibakenar and Kiashahr lagoons, respectively, 272 indicating considerable contamination. Copper $(\mathrm{CF}=1.53), \mathrm{Pb}(\mathrm{CF}=1.46), \mathrm{V}(\mathrm{CF}=1.10)$ and $273 \mathrm{Zn}(\mathrm{CF}=1.35)$ show moderate contamination in the Zibakenar lagoon. The Kiashahr lagoon 274 sediments are moderately contaminated with $\mathrm{Cu}(\mathrm{CF}=1.63)$ and $\mathrm{Pb}(\mathrm{CF}=1.63)$, low 275 contaminated with $\mathrm{V}(\mathrm{CF}=0.84)$, and considerably contaminated with $\mathrm{Zn}(\mathrm{CF}=3.83)$. 
276 The order of mean $\mathrm{CF}$ values is $\mathrm{Pb}>\mathrm{Cu}>\mathrm{Zn}>\mathrm{Co}>\mathrm{Ni}>\mathrm{V}>\mathrm{Cr}$ for Amirkola

277 Lagoon, $\mathrm{Co}>\mathrm{Cu}>\mathrm{Pb}>\mathrm{Zn}>\mathrm{V}>\mathrm{Ni}>\mathrm{Cr}$ for Zibakenar Lagoon, and $\mathrm{Co}>\mathrm{Zn}>$ $278 \mathrm{Cu}=\mathrm{Pb}>\mathrm{V}>\mathrm{Ni}>$ Cr for Kiashahr Lagoon.

279 According to the mean PLI values, the samples taken from all three lagoons are unpolluted 280 with studied metals. As is evident in Table 5, the highest PLI value in the Amirkola Lagoon is 281 less than 1 and indicates that all samples of this lagoon have no metal pollution. Since the 282 Zibakenar and Kiashahr lagoons' maximum PLI values are higher than 1, some samples in 283 those lagoons show metal pollution. About $85.7 \%$ of the Zibakenar Lagoon and $67.8 \%$ of the 284 Kiashahr Lagoon samples had PLI higher than 1 and showed different degrees of metal 285 pollution (Fig. 6). The PLI value of the whole lagoon is 0.24 for Amirkola, 1.05 Zibakenar and 2861.12 for Kiashahr lagoons, which confirmed that metal pollution had increased from the 287 Amirkola Lagoon to the Zibakenar and Kiashahr lagoons.

\section{3.4. Metal source}

289 The Sefidrud delta is the largest in the southern Caspian Sea formed in the Pleistocene. This 290 delta is wave-dominated during the sea-level rise and river-dominated when sea-level falls 291 (Naderi Beni et al., 2013). The Sefidrud course has been frequently changed between the Anzali and Amirkola lagoons (Kousari, 1986). The last major avulsion had occurred in AD 1600 when the river course was shifted from the east, near the present Amirkola Lagoon, towards the west

294 near the current Kiashahr Lagoon (Krasnozhon et al., 1999; Lahijani et al., 2009; Kazanc1 and 295 Gulbabazadeh, 2013). The Sefidrud before the latest avulsion is known as Old Sefidrud and 296 New Sefidrud (or Sefidrud) after avulsion. Old Sefidrud created the Amirkola Lagoon, and 297 New Sefidrud formed the Zibakenar and Kiashahr lagoons.

298 Most of the sediments entered into the delta are transported to the coast by the Sefidrud River. 299 Then the origin of sediments in all three lagoons is the same due to a common geological 300 source. The total concentration of elements is expected to be approximately similar in the 
301 lagoons. However, the chemical analysis results indicate differences in the amount of some 302 heavy metals in the lagoons.

303 Despite the common geological origin of sediments, toxic metals are not uniformly distributed 304 in studied lagoons. Based on the metals distribution and pollution indices, no metal 305 contamination is observed in Amirkola Lagoon, which is formed about 500 years ago. Lead 306 has increased in surface sediments of this lagoon. Lead variation in the core taken from the 307 Amirkola Lagoon shows an increase in $\mathrm{Pb}$ content in the uppermost portion of the core (Fig. 308 5).

309 As presented in Table 4, the similarity of $\mathrm{I}_{\text {geo }}$ values for $\mathrm{Cr}$ and $\mathrm{Ni}$ show the same origin for 310 these metals in all studied lagoons. Considering the same geogenic origin of the sediments 311 entering into all studied lagoons, the observed differences in $I_{g e o}$ values might be from the 312 anthropogenic origin. In the newly-formed Zibakenar and Kiashahr lagoons, the distribution 313 map of elements (Fig. 4) shows that the scattering pattern of some metals is different in the two 314 lagoons. On the other hand, in Kiashahr Lagoon, $\mathrm{Zn}$ and Co had the highest pollution level, 315 while in Zibakenar Lagoon, Co indicates the highest contamination level. Differences in the

316 amount and type of heavy metals can indicate an anthropogenic source. The pattern of 317 increasing element concentration towards some recreational and touristic facilities and 318 particular areas also increases the role of anthropogenic-originated pollutants. Statistical 319 analysis was performed to investigate the origin of metals in sediment samples and differences 320 in element contents of the three studied lagoons.

\section{3.4.1. Correlation Matrix}

322 Pearson's correlation coefficients of elements in studied lagoons are summarized in Table 6. 323 Correlation matrix for the Amirkola Lagoon shows that $\mathrm{Cr}, \mathrm{Cu}, \mathrm{Fe}, \mathrm{K}, \mathrm{Mg}, \mathrm{Na}, \mathrm{Ti}, \mathrm{V}, \mathrm{Zn}$ and $324 \mathrm{Zr}$ have a strong positive correlation with $\mathrm{Al}$, and $\mathrm{Ba}, \mathrm{Ca}, \mathrm{Mn}$ and $\mathrm{Sr}$ have a strong negative 325 correlation with $\mathrm{Al}$ (Table 6). The first group belongs to silicate minerals, and the second one 
326 belongs to carbonate minerals in sediment samples of this lagoon. Nickel, $\mathrm{P}$ and $\mathrm{Pb}$ show no

327 positive nor negative correlation with Al. Lead only has a strong positive correlation with $\mathrm{Ni}$,

328 indicating the exact behaviour of these elements.

329 In the Zibakenar Lagoon, the relationship between elements changes (Table 6). Aluminum as

330 a geogenic element has a strong positive relationship with $\mathrm{Cu}, \mathrm{K}, \mathrm{Mg}$ and $\mathrm{Ni}$ and does not show

331 a clear relationship with other elements. Heavy metals such as $\mathrm{Co}, \mathrm{Cr}, \mathrm{Fe}, \mathrm{Pb}, \mathrm{Ti}, \mathrm{V}, \mathrm{Zn}$ and $\mathrm{Zr}$

332 have a strong positive relationship and have no significant relationship with other studied

333 elements.

334 In the Kiashahr Lagoon, these relationships are entirely different from the other two lagoons

335 (Table 6). Aluminum has a strong positive relationship with $\mathrm{Co}, \mathrm{Cr}, \mathrm{Cu}, \mathrm{Fe}, \mathrm{Ni}, \mathrm{Ti}, \mathrm{V}$ and $\mathrm{Zr}$,

336 and a very strong negative relationship with $\mathrm{Ca}$ and $\mathrm{Sr}$. In this lagoon, unlike the Amirkola

337 Lagoon, $\mathrm{Zn}$ has no relation with $\mathrm{Al}$, and on the contrary, Ni has a strong relationship with $\mathrm{Al}$.

338 Lead and $\mathrm{Zn}$ do not show any correlation with other heavy metals.

339 Since the entrance sediments of all studied lagoons have the same geological source, the

340 detected changes in metal correlations might be a cause of an anthropogenic source for some

341 metals.

\section{$342 \quad 3.4 .2$. Analysis of variance}

343 One-way analysis of variance (ANOVA) was achieved to compare the studied lagoons in terms 344 of metal content and find the differences between them. At first, the residual values of the 345 model were examined, and their normality was tested (Table 7). This test shows that the

346 residual values are not normal except for $\mathrm{Co}$, but it should be noted that Co can only be 347 measured in 5 samples in the Amirkola Lagoon and was below the detection limit in 51 348 samples. The same thing goes for $\mathrm{Pb}$ and $\mathrm{Ni}$ were not detectable in all samples of the Amirkola 349 Lagoon. The $\mathrm{Pb}$ and $\mathrm{Ni}$ concentrations were above the detection limit in 16 and 23 samples, 350 respectively . 
351 Therefore, due to the normality of the model's residual values, The nonparametric equivalent

352 of the one-way analysis of variance (Kruskal-Wallis test) was used to compare the three

353 lagoons. Based on the results presented in Table 8, all studied metals show significant 354 differences in error level of one percent in all three lagoons $(P<\alpha=0.01)$ but $\mathrm{Pb}$ due to many 355 missing samples in the Amirkola Lagoon. Therefore, the Mann-Whitney test with the 356 Bonferroni method was used for pairwise comparison in studied lagoons.

\section{3.4.3. Two-Step Cluster Analysis}

358 As the nonparametric analysis of variance showed a difference between the three lagoons, a 359 two-step cluster analysis was used to find the similarities and differences in the metal content 360 of the studied lagoons. The Two-Step Cluster Analysis is used as an investigation tool to 361 disclose natural groupings (or clusters) in a dataset that would otherwise not be clear. For this 362 purpose, all samples taken from each lagoon were placed in the same group then were recategorized using this method. Cobalt, $\mathrm{Ni}$ and $\mathrm{Pb}$ in the Amirkola Lagoon were put aside from

364 the analysis due to a considerable amount of missing data.

365 Various measures are used to quantify the "goodness" of a cluster solution. In a good cluster 366 solution, the elements within a cluster are similar to one (cohesive), while the clusters 367 themselves are quite different (separated). A popular measure is the silhouette coefficient, 368 which is a measure of both cohesion and separation. In a good solution, the within-cluster 369 distances are small, and the between cluster distances are large, resulting in a silhouette 370 measure close to the maximum value of 1 (Fig. 7a). The distribution of cases in the final cluster 371 solution is seen in Fig. 7a. Out of 106 samples taken from all three lagoons, 50 samples were 372 placed in cluster 1 and 56 samples in cluster 2. Cluster 2 consists of all the Amirkola Lagoon samples, and the first cluster consists of all samples from the Zibakenar and Kiashahr lagoons.

374 As expected, the Amirkola Lagoon, formed on the old Sefidrud Delta, is entirely different from 
375 the two newer lagoons in terms of metal content. Figure $7 \mathrm{~b}$ also ranks the features from the 376 most to the least importance.

377 Aluminum and $\mathrm{Zr}$ had the highest, and $\mathrm{Zn}$ had the least importance on separating two clusters.

378 The differences in $\mathrm{Al}, \mathrm{Zr}, \mathrm{Cu}, \mathrm{Fe}$ and $\mathrm{Ti}$ contents between the Amirkola Lagoon and the other 379 two lagoons caused the separation of these two groups from each other.

380 The Mann-Whitney test with the Bonferroni adjustment method is used to perform pairwise 381 comparisons. To apply the Bonferroni adjustment, the $p$-value obtained from the MannWhitney test should multiply by the number of pairwise comparisons and then compare with 383 the error rate of the first type $(\alpha)$ (Tabachnick and Fidell, 2012). In this study, considering that 384 the number of comparisons is 3 , Bonferroni $p$ is as follow: Bonferonni $p=3 \times(p-$ value $)$

386 If Bonferroni $p$ is greater than one, the value of Bonferroni $p$ is considered one.

\section{$387 \quad 3.4 .4$. Independent samples t-test}

388 The results of the independent samples t-test are presented in Table 9. There are significant 389 differences between the Zibakenar and Kiashahr lagoons and the Amirkola Lagoon for all 390 studied metals except $\mathrm{Pb}$ because of the latter lagoon's missing data. The mean values of studied 391 metals in the Zibakenar and Kiashahr lagoons are higher than Amirkola Lagoon (Table 3). In 392 other words, the distributions of these metals in three lagoons are entirely different.

393 The result of comparing the two Zibakenar and Kiashahr lagoons reveals remarkable 394 information. The difference between the studied metals in these two lagoons is not significant. 395 In other words, these metals are similar in terms of distribution and value. Only two elements 396 of $\mathrm{Zn}$ and $\mathrm{Ni}$ have significant differences in these lagoons. The mean values of $\mathrm{Pb}$ in the 397 Zibakenar and Kiashahr lagoons were 90.41 and $247.02 \mathrm{mg} / \mathrm{kg}$, and the mean values of Ni were 39838.87 and $34.54 \mathrm{mg} / \mathrm{kg}$, respectively. The significant difference in $\mathrm{Zn}$ values in two lagoons of 399 the same geogenic origin can only be justified with an anthropogenic source. 
400 It seems high Zn pollution indices in the Kiashahr Lagoon are due to human impact on sediment 401 pollution. The mean value of $\mathrm{Ni}$ in the Kiashahr Lagoon was lower than Zibakenar, while the highest concentration of this metal was observed in the Kiashahr Lagoon. Most samples of the

403 Zibakenar Lagoon have higher Ni content than the Kiashahr Lagoon samples. Perhaps this 404 significant difference in the concentration of $\mathrm{Ni}$ in the two lagoons is due to the local airport 405 and touristic facilities next to the Zibakenar Lagoon.

406

\section{4. Conclusion}

408 The Sefidrud Delta is the largest in the south of the Caspian Sea, formed during the Holocene. 409 Amirkola, Zibakenar and Kiashahr are the most important lagoons that are created during this 410 delta formation. According to the previous studies (Jedari Eivazi et al., 2005; Leroy et al., 2011; 411 Kazancı and Gulbabazadeh, 2013; Haghani, 2015), Amirkola Lagoon was created 500 years 412 ago by Old Sefidrud. The other two young lagoons result from the current activity of the 413 Sefidrud River created over the past few decades .

414 Physicochemical properties of sediment samples, heavy metals content and their distribution 415 were investigated in all three lagoons. The physicochemical properties of sediment samples 416 show that the average organic matter, carbonate content and sand percentage in Amirkola 417 Lagoon sediments are more than the other two lagoons. In contrast, the Zibakenar and Kiashahr 418 lagoons are mainly muddy and have a lower amount of sand. Comparing $\mathrm{Cr}, \mathrm{Cu}, \mathrm{Co}, \mathrm{Ni}, \mathrm{Pb}$, $419 \mathrm{Ti}, \mathrm{V}, \mathrm{Zn}$, and $\mathrm{Zr}$ contents in the lagoons shows that the average of these metals in Amirkola 420 Lagoon is significantly less than the other lagoons. Kiashahr Lagoon's age and the most 421 negligible anthropogenic impacts play an essential role in this difference. Through the past 500 422 years, the geological source of the Sefidrud River sediment has not changed. During recent 423 years, the increase of human activities in the delta and its upstream areas, such as dam 424 construction, various industries and factories, and agricultural activities (e.g. using fertilizers 
and pesticides), has considerably augmented heavy metals concentrations in the Zibakenar and

426 Kiashahr lagoons .

427 Low CF and PLI values for metals and sediments in the Amirkola Lagoon reveal geogenic 428 sources for studied metals. This fact was supported by Igeo $(<0)$ index as well. The CF and Igeo 429 values for $\mathrm{Cu}, \mathrm{Cr}, \mathrm{Co}, \mathrm{Ni}, \mathrm{Zn}$ and $\mathrm{V}$ showed an unpolluted status. Lead shows moderate $\mathrm{CF}$ 430 values (average CF 1.43), indicating anthropogenic sources. On the other hand, sediment 431 samples of the Zibakenar and Kiashahr lagoons showed high $\mathrm{CF}$ values for $\mathrm{Co}, \mathrm{Zn}, \mathrm{Cu}$ and $\mathrm{Pb}$, 432 while $\mathrm{I}_{\mathrm{geo}}$ showed high values for Co and $\mathrm{Zn}$. According to the PLI values, most of the 433 Zibakenar and Kiashahr lagoons samples were polluted (PLI > 1), suggesting inputs from 434 anthropogenic sources. The Amirkola Lagoon was found to be uncontaminated based on the 435 lagoon PLI values, but the Zibakenar and Kiashahr lagoons were considered to be 436 contaminated.

437 Statistical analyses showed significant differences in heavy metal contents between the 438 Amirkola and two other studied lagoons. The sediment samples were taken from the Amirkola 439 Lagoon display meaningful lower metal concentrations than the other two.

440 Also, two recently formed Zibakenar and Kiashahr lagoons show differences in $\mathrm{Zn}$ and $\mathrm{Ni}$ 441 contents. The Kiashahr Lagoon is connected to the Caspian Sea through a canal linking 442 Kiashahr harbour to the sea. The high amount of $\mathrm{Zn}$ in the sediments of this lagoon is related 443 to the passing of fishing boats and yachts through this route. Zibakenar Lagoon is also located 444 near a small local airport and recreational and touristic centre. The increasing Ni content in the 445 sediments, especially in the southern part of the lagoon, can be related to these facilities. For 446 centuries, the primary source of sediments and heavy metals of the Sefidrud Delta deposits has 447 been the Sefidrud River sediments. A new source of sediment contaminants in this delta is 448 human impacts and activities (domestic, industrial and agricultural) developed during the past 449 few decades. 
450 An increase in $\mathrm{Zn}$ and $\mathrm{Pb}$ contents was observed from the bottom to the top of the cores taken 451 from all three lagoons, but it is much more dramatic in the Zibakenar and Kiashahr lagoons. 452 Since the primary source of sediments stayed the same, human activities and anthropogenic 453 sources are appeared to be the main source of heavy metals in the studied lagoons during the 454 past decades.

455

456 Acknowledgements

457 The authors wish to thank the Bu-Ali Sina University for the financial support and Geological 458 Survey of Iran (GSI), Department of Marine Geology (Projects No. 92231352 and 92231353 ) 459 for sampling and instrumental analyses.

460

461 Declarations

462 Funding: Funder is Bu-Ali Sina University, Hamedan-Iran; award number is 98223463 2.11.2019; Grant Recipient is Behrouz Rafiei.

464 Conflicts of interest/Competing interests: The authors declare that they have no known 465 competing financial interests or personal relationships that could have appeared to influence 466 the work reported in this paper.

467 Data Availability: Not applicable

468 Author contribution:

469 1. Behrouz Rafiei: Supervisor of two MSc theses achieved at Bu-Ali Sina University, 470 wrote the manuscript. Performed some statistical calculations. 
2. Fatemeh Ahmadi-Ghomi: Developed the manuscript and performed the computations, drew some figures and translated the material. discussed the results and contributed to the final manuscript.

3. Asghar Seif: Introduced and performed the statistical method and calculations.

4. Ali Shakibaazad: Advisor of two MSc theses achieved at Bu-Ali Sina University and conducted some analytical procedures at Geological Survey of Iran.

5. Sonia Shamshiri: Her MSc. thesis is part of the manuscript

6. Zahra Sharifi Abzahli: Her MSc. thesis is part of the manuscript

Consent to participate: Not applicable

Consent to publish: Not applicable

\section{References}

Annels, R.N., Arthurton, R.S., Bazley, R.A., Davies, R.G. 1975. Explanatory Text of the Qazvin and Rasht Quadrangles. Geological Survey of Iran, E3 and E4 Maps, 94p, Tehran.

Beraldi, G.Q.F., de Rezende, C.E., de Almeida, M.G., Carvalho, C., de Lacerda, L.D., de Farias, R.N., Vidal, M., Souza, M.D.P., Molisani, M.M. 2019. Assessment of a coastal lagoon metal distribution through natural and anthropogenic processes (SE, Brazil). Marine Pollution Bulletin, 146: 552-561. DOI: 10.1016/j.marpolbul.2019.07.007

Caeiro, S., Costa, M.H., Ramos, T.B., Fernandes, F., Silveira, N., Coimbra, A., Medeiros, G., Painho, M. 2005. Assessing heavy metal contamination in Sado Estuary sediment: an index analysis approach. Ecological Indicators, 5: 151-169. DOI: 10.1016/j.ecolind.2005.02.001 
Carver, R.E. 1971. Procedures in sedimentary petrology. Wiley-Interscience, New York, 653

p.

497

498

499

500

501

502

503

504

505

506

507

508

509

510

511

512

513

514 Heiri, O., Lotter, A.F., Lemcke, G. 2001. Loss on ignition as a method for estimating organic 515

516

517

518

Chen, Z., Salem, A., Xu, Z., Zhang, W. 2010. Ecological implications of heavy metal concentrations in the sediments of Burullus Lagoon of Nile Delta, Egypt. Estuarine, Coastal and Shelf Science, 86: 491-498. DOI:10.1016/j.ecss.2009.09.018

Etemadi Deilami, A., Jensi, Z., Ziksari, M., Mirzaei, M., Izad Doust, H., Bouzari, Z., Mohamadi, Y. 2010. The study of ecologic fauna in Amirkola Lagoon, Gilan Province. $2^{\text {nd }}$ National Wetland Conference, Ahvaz, Iran, wetland 02-009.

Folk, R.L. (1980) Petrology of Sedimentary Rocks. Hemphill Publishing Co., Austin, 190 p.

García, G., Muñoz-Vera, A. 2015. Characterization and evolution of the sediments of a Mediterranean coastal lagoon located next to a former mining area. Marine Pollution Bulletin, 100: 249-263. DOI: 10.1016/j.marpolbul.2015.08.042

Haghani, S. 2015. Evolution of the Sefidrud Delta (South West Caspian Sea) during the last millennium. Ph.D. thesis, Brunel University London, England, 159 p.

Håkanson, L. 1980. An ecological risk index for aquatic pollution control. A sedimentological approach. Water Research, 14: 975-1001. DOI: 10.1016/0043-1354(80)90143-8

Harikumar, P.S., Jisha, T.S. 2010. Distribution pattern of trace metal pollutants in the sediments of an urban wetland in the Southwest Coast of India. International Journal of Engineering Science and Technology, 2 (5): 840-850. and carbonate content in sediments: reproducibility and comparability of results. Journal of Paleolimnology, 25: 101-110. DOI: 10.1023/A:1008119611481

Hou, D., He, J., Lu, C., Ren, L., Fan, Q., Wang, J., Xie, Z. 2013. Distribution characteristics and potential ecological risk assessment of heavy metals $(\mathrm{Cu}, \mathrm{Pb}, \mathrm{Zn}, \mathrm{Cd})$ in water and 
sediments from Lake Dalinouer, China. Ecotoxicology and Environmental Safety, 93:

Jedari Eivazi, J., Yamani M., Khoshraftar, R. 2005. Sefidrud River Delta Geomorphological Evolution in Quarternary. Geographical Research, 38(1): 99-120.

Kazanc1, N., Gulbabazadeh, T. 2013. Sefidrud delta and quaternary evolution of the southern Caspian Lowland, Iran. Marine and Petroleum Geology, 44: 120-139. DOI: 10.1016/j.marpetgeo.2013.03.006

Kazanci, N., Gulbabazadeh, T., Leroy, S.A.G., Ileri, O. 2004. Sedimentology and environmental characteristics at the Guilan-Mazenderan plain, northern Iran; influence of long- and short-term Caspian level fluctuations on geomorphology. Journal of Marine Systems, 46: 154-168. DOI: 10.1016/j.jmarsys.2003.12.002

Kjerfve, B. 1994. Coastal lagoons. Elsevier oceanography series, 60: 1-8.

Kousari, S. 1986. Evolution of Sefidrud Delta. Development in Geological Education, 1: 3141 (in Persian).

Krasnozhon, G.F., Lahijani, H., Voropayev, G.V. 1999. Evolution of the delta of the Sefidrud River, Iranian Caspian Sea coast, from space imagery. Mapping Science and Remote Sensing, 36: 256-264. DOI: 10.1080/07493878.1999.10642127

Lahijani, H.A.K., Rahipour-Bonab, H., Tavakoli, V., Hosseindoust, M. 2009. Evidence for late Holocene highstand in Central Guilan-East Mazandaran, south Caspian Coast, Iran. Quaternary International, 197: 55-71. DOI: 10.1016/j.quaint.2007.10.005

Leroy, S.A.G., Lahijani, H.A.K., Djamali, M., Naqhinezhad, A., Moghadam, M.V., Arpe, K., Shah-Hosseini, M., Hosseindoust, M., Miller, Ch.S., Tavakoli, V. Habibi, P. Naderi Bani, M. 2011. Late little ice age palaeoenvironmental records from the Anzali and Amirkola Lagoons (south Caspian Sea): Vegetation and sea-level changes. Journal of 
Paleogeography, Paleoclimatology, Paleoecology, 302: 415-434. DOI: 10.1016/j.palaeo.2011.02.002

545 Lewis, D.W., McConchie, D. 1994. Analytical sedimentology. Chapman and Hall, New York, 546 197 p.

547 Müller, G. 1969. Index of geo-accumulation in sediments of the Rhine River. Geological $548 \quad$ Journal, 2: 108-118.

549 Müller, G. 1981. Die schwermetallbelstung der sedimente des neckars und seiner nebenflusse: eine estandsaufnahme. Chemiker Zeitung, 105: 157-164.

551 Naderi Beni, A., Lahijani, H., Harami, R.M., Leroy, S.A.G., Shah-Hosseini, M., Kabiri, K. and Tavakoli, V. 2013. Development of spit-lagoon complexes in response to Little Ice Age rapid sea-level changes in the central Guilan coast, South Caspian Sea, Iran. Geomorphology, 187: 11-26. DOI: 10.1016/j.geomorph.2012.11.026

Ontiveros-Cuadras, J.F., Ruiz-Fernández, A.C., Pérez-Bernal, L.H., Serrato de la Peña, J.L., Sanchez-Cabeza, J.A. 2019. Recent trace metal enrichment and sediment quality assessment in an anthropized coastal lagoon (SE Gulf of California) from ${ }^{210} \mathrm{~Pb}$-dated sediment cores. Marine Pollution Bulletin, 149

(3): 110653. DOI: 10.1016/j.marpolbul.2019.110653

560 Qingjie, G., Jun, D. 2008. Calculating pollution indices by heavy metals in ecological 561 geochemistry assessment and a case study in parks of Beijing. Journal of China University of Geosciences, 19 (3): 230-241. DOI: 10.1016/S1002-0705(08)60042-4

Rafiei, B., Ahmadi Ghomi, F., Ardebili L., Sadeghifar M. and Khodaparast Sharifie H. 2012. Distribution of metals $(\mathrm{Cu}, \mathrm{Zn}, \mathrm{Pb}$ and $\mathrm{Cd})$ in sediments of the Anzali Lagoon, North Iran. Soil and Sediment Contamination An International Journal, 21 (6): 768-787. DOI: $10.1080 / 15320383.2012 .678953$ 
567 Rafiei, B., Ahmadi-Ghomi, F., Karimkhani, A. 2017. Assessment of anthropogenic influx of metallic pollutants in the Sefidrud delta, Gilan Province, Iran. Marine Pollution Bulletin, 121: 381-389. DOI: 10.1016/j.marpolbul.2017.06.021

570 Rafiei, B., Movasagh, A., Karimkhani, A., Sadeghifar, M. 2015. Distribution of heavy metals in surficial sediments of the Anzali Lagoon outlet, North Iran. Applied sedimentology, 2(4): 1-15.

Romano, E., Bergamin, L., Croudace, I.W., Pierfranceschi, G., Sesta, G., Ausili, A. 2021. Measuring anthropogenic impacts on an industrialised coastal marine area using chemical and textural signatures in sediments: A case study of Augusta Harbour (Sicily, Italy). Science of the Total Environment, 755: 142683. DOI: 10.1016/j.scitotenv.2020.142683

Rudnick, R. L., Gao, S. 2003. Composition of the continental crust. In: Treatise on 579 geochemistry- The Crust. Rudnick, R. L., Holland, H.D. and Turekian, K.K. (Editors), Elsevier, Oxford. pp. 1-64.

Sarvar, J. 2008. Change of Sefidrud's channel on its delta since 1982 until 2008. Territory, 20: 83-106.

Segura, R., Arancibia, V., Zuniga, M.C., Pasten, P. 2006. Distribution of copper, zinc, lead and cadmium concentrations in stream sediments from the Mapocho River in Santiago, Chile. Journal of Geochemical Exploration, 91: 71-80. DOI:

Suresh, G., Sutharsan, P., Ramasamy, V., Venkatachalapathy, R. 2012. Assessment of spatial distribution and potential ecological risk of the heavy metals in relation to granulometric contents of Veeranam Lake sediments, India. Ecotoxicology and Environmental Safety, 84: 117-124. DOI: 10.1016/j.ecoenv.2012.06.027 
591 Tabachnick, B.G., Fidell, L.S. 2012. Using multivariate statistics (6 $6^{\text {th }}$ Ed.). New York, HarperCollins, 983 pp.

593 Tomlinson, D.L., Wilson, J.G., Harris, C.R., Jeffrey, D.W. 1980. Problems in the assessment of heavy-metal levels in estuaries and the formation of a pollution index. Helgoländer Meeresun. 33: 566-575.

Uluturhan, E., Kontas, A., Can, E. 2011. Sediment concentrations of heavy metals in the Homa Lagoon (Eastern Aegean Sea): Assessment of contamination and ecological risks. Marine Pollution Bulletin, 62: 1989-1997. DOI: 10.1016/j.marpolbul.2011.06.019

600

601

Vesali Naseh, M.R., Karbassi, A., Ghazaban, F., Baghvand, A. 2012. Evaluation of Heavy metal Pollution in Anzali Wetland, Guilan, Iran. Iranian Journal of Toxicology, 5(15): $565-576$.

Wang, Z., Wang, Y., Chen, L., Yan, C., Yan, Y., Chi, Q. 2015. Assessment of metal 603 contamination in coastal sediments of the Maluan Bay (China) using geochemical indices and multivariate statistical approaches. Marine Pollution Bulletin, 99: 43-53. DOI: 10.1016/j.marpolbul.2015.07.064

607

608

609

Yamani M., Moghimi E., Motamed A., Jafarbeglo M., Lorestani Gh. 2013. Fast Shoreline Changes in Sefidrud Delta Using Transects Analyses Method. Physical Geography contamination in the surface sediments of Po delta lagoons (Italy). Estuarine, Coastal and Shelf Science, 225: 106235. DOI: 10.1016/j.ecss.2019.05.017 


\section{Figure captions}

617 Fig.1. Location map and sampling points of the studied lagoons. (ZKL: Zibakenar Lagoon;

618 KSL: Kiashahr Lagoon; AKL: Amirkola Lagoon). Red squares indicate the core sample

619 location in each lagoon.

620 Fig. 2. Textural classification of studied samples in three lagoons based on Folk (1980). (Black

621 circles: Zibakenar samples; Red circles: Kiashahr samples; Yellow circles: Amirkola samples)

622 Fig. 3. Box plot diagram of metal concentrations in studied lagoons.

623 Fig. 4. Distribution map of some studied metals in the Zibakenar and Kiashahr lagoons.

624 Fig. 5. Sedimentary facies and heavy metals concentrations changes in core samples taken from

625 studied lagoons. The Amirkola Lagoon sediments are temporally different from the others.

626 Fig. 6. Box Plot diagram of PLI values in all three lagoons.

627 Fig. 7. Results of two-step cluster analysis, a) Silhouette measure shows values close to the 628 maximum amount, and cluster sizes including two distinct clusters; b) features from the most 629 to the least predictor (variable) importance.

630

Table 1. Classification of pollution indices used in this study.

\begin{tabular}{ccc}
\hline Index & Class & Description \\
\hline & $\mathrm{I}_{\text {geo }} \leq 0$ & Practically uncontaminated \\
& $0<\mathrm{I}_{\text {geo }} \geq 1$ & Uncontaminated to moderately contaminated \\
Geo-accumulation & $1<\mathrm{I}_{\text {geo }} \geq 2$ & Moderately contaminated \\
(Müller, 1969) & $2<\mathrm{I}_{\text {geo }} \geq 3$ & Moderately to heavily contaminated \\
& $3<\mathrm{I}_{\text {geo }} \geq 4$ & Heavily contaminated \\
& $4<\mathrm{I}_{\text {geo }} \geq 5$ & Heavily to extremely contaminated \\
& $5<\mathrm{I}_{\text {geo }}$ & Extremely contaminated \\
Contamination & $\mathrm{CF} \geq 1$ & Low contamination \\
factor & $1<\mathrm{CF} \geq 3$ & Moderate contamination \\
(Häkanson, 1980) & $3<\mathrm{CF} \geq 6$ & Considerable contamination \\
& $\mathrm{CF}<6$ & Very high contamination \\
\hline
\end{tabular}

632

633

634

635

636 
638 Table 2. Summarized physicochemical properties of studied samples in three lagoons.

639

\begin{tabular}{lcccccc}
\hline & \multicolumn{2}{c}{ Amirkoal Lagoon (56) } & \multicolumn{2}{c}{ Kiashahr Lagoon (28) } & \multicolumn{2}{c}{ Zibakenar Lagoon (22) } \\
\cline { 2 - 7 } & Range & Mean & Range & Mean & Range & Mean \\
\hline Gravel (\%) & $0.25-88.68$ & $\mathbf{9 . 2 5}$ & $0.12-36.91$ & $\mathbf{5 . 5 9}$ & $0.38-51.91$ & $\mathbf{9 . 6 9}$ \\
Sand (\%) & $4.55-93.3$ & $\mathbf{4 2 . 1 3}$ & $5.52-80.62$ & $\mathbf{2 6 . 5 5}$ & $5.48-96.80$ & $\mathbf{2 0 . 5 9}$ \\
Clay (\%) & $3.6-68.71$ & $\mathbf{4 8 . 4 5}$ & $0.00-89.05$ & $\mathbf{5 6 . 5}$ & $1.63-87.17$ & $\mathbf{5 9 . 2 0}$ \\
Carbonate (\%) & $4.58-79.16$ & $\mathbf{5 4 . 4 9}$ & $8.00-66.65$ & $\mathbf{4 3 . 3 0}$ & $23.53-66.65$ & $\mathbf{4 4 . 4 0}$ \\
Organic matter (\%) & $9.25-65.78$ & $\mathbf{2 1 . 0 1}$ & $1.00-15.00$ & $\mathbf{9 . 9 6}$ & $2.00-28.00$ & $\mathbf{1 1 . 5 2}$ \\
pH & $7.09-8.24$ & $\mathbf{7 . 7 5}$ & $7.10-7.97$ & $\mathbf{7 . 5 8}$ & $6.90-7.88$ & $\mathbf{7 . 5 3}$ \\
\hline
\end{tabular}

640

641 Table 3. Descriptive statistics of some major and minor element concentrations in sediment 642 samples of the studied lagoons

\begin{tabular}{|c|c|c|c|c|c|c|c|c|c|c|c|c|}
\hline \multirow{2}{*}{$\begin{array}{l}\text { Eleme } \\
\text { nt }\end{array}$} & \multicolumn{4}{|c|}{ Amirkola $(n=56)$} & \multicolumn{4}{|c|}{ Zibakenar $(\mathrm{n}=22)$} & \multicolumn{4}{|c|}{ Kiashahr $(\mathrm{n}=28)$} \\
\hline & Range & $\begin{array}{l}\text { Mea } \\
\mathrm{n}\end{array}$ & $\begin{array}{l}\text { Med } \\
\text { ian }\end{array}$ & $\mathrm{SD}$ & Range & $\begin{array}{l}\text { Mea } \\
\mathrm{n} \\
\end{array}$ & $\begin{array}{l}\text { Med } \\
\text { ian }\end{array}$ & SD & Range & $\begin{array}{l}\text { Mea } \\
\mathrm{n}\end{array}$ & $\begin{array}{l}\text { Med } \\
\text { ian }\end{array}$ & $\mathrm{SD}$ \\
\hline Al (\%) & $\begin{array}{l}0.32- \\
3.86\end{array}$ & 0.99 & 0.61 & $\begin{array}{l}0.7 \\
6\end{array}$ & $\begin{array}{l}0.91- \\
9.27\end{array}$ & 7.91 & 8.24 & 1.68 & $4.17-9.41$ & 6.97 & 7.31 & $\begin{array}{l}1.6 \\
5\end{array}$ \\
\hline $\mathrm{Fe}(\%)$ & $\begin{array}{l}0.30- \\
4.81\end{array}$ & 1.01 & 0.75 & $\begin{array}{l}0.8 \\
5\end{array}$ & $\begin{array}{l}0.84- \\
8.20\end{array}$ & 4.25 & 4.10 & 1.35 & $2.24-5.66$ & 3.97 & 4.24 & $\begin{array}{l}0.9 \\
6\end{array}$ \\
\hline $\begin{array}{l}\mathrm{Ca} \\
(\%)\end{array}$ & $\begin{array}{l}3.59- \\
40.00\end{array}$ & $\begin{array}{l}24.2 \\
8\end{array}$ & $\begin{array}{l}25.4 \\
2\end{array}$ & $\begin{array}{l}5.8 \\
5\end{array}$ & $\begin{array}{l}5.01- \\
11.65\end{array}$ & 8.77 & 8.78 & 1.87 & $\begin{array}{l}6.53- \\
20.36\end{array}$ & $\begin{array}{l}12.2 \\
1\end{array}$ & $\begin{array}{l}10.9 \\
1\end{array}$ & $\begin{array}{l}3.8 \\
8\end{array}$ \\
\hline $\mathbf{K}(\%)$ & $\begin{array}{l}0.07- \\
0.98\end{array}$ & 0.24 & 0.15 & $\begin{array}{l}0.1 \\
9\end{array}$ & $\begin{array}{l}0.36- \\
2.27\end{array}$ & 1.95 & 2.00 & 0.38 & $1.02-2.36$ & 1.69 & 1.77 & $\begin{array}{l}0.4 \\
1\end{array}$ \\
\hline $\begin{array}{l}\mathrm{Mg} \\
(\%)\end{array}$ & $\begin{array}{l}0.54- \\
1.08\end{array}$ & 0.74 & 0.72 & $\begin{array}{l}0.0 \\
9\end{array}$ & $\begin{array}{l}0.53- \\
1.56\end{array}$ & 1.41 & 1.45 & 0.21 & $1.25-1.67$ & 1.47 & 1.45 & $\begin{array}{l}0.1 \\
3\end{array}$ \\
\hline $\begin{array}{l}\mathrm{Na} \\
(\%)\end{array}$ & $\begin{array}{l}0.10- \\
0.67\end{array}$ & 0.23 & 0.20 & $\begin{array}{l}0.1 \\
1\end{array}$ & $\begin{array}{l}0.19- \\
1.83\end{array}$ & 0.86 & 0.77 & 0.34 & $0.44-1.54$ & 0.96 & 0.93 & $\begin{array}{l}0.3 \\
4\end{array}$ \\
\hline $\begin{array}{l}\text { Mn } \\
(\mathrm{mg} / \mathrm{k} \\
\mathrm{g})\end{array}$ & $\begin{array}{l}595.94- \\
3506.05\end{array}$ & $\begin{array}{l}151 \\
1.18\end{array}$ & $\begin{array}{l}143 \\
5.93\end{array}$ & $\begin{array}{l}619 \\
.69\end{array}$ & $\begin{array}{l}484.30- \\
1594.06\end{array}$ & $\begin{array}{l}111 \\
7.92\end{array}$ & $\begin{array}{l}111 \\
7.98\end{array}$ & $\begin{array}{l}256 . \\
67\end{array}$ & $\begin{array}{l}875.60- \\
1937.58\end{array}$ & $\begin{array}{l}138 \\
3.73\end{array}$ & $\begin{array}{l}142 \\
3.00\end{array}$ & $\begin{array}{l}269 \\
.17\end{array}$ \\
\hline $\begin{array}{l}\mathrm{Cr} \\
(\mathrm{mg} / \mathrm{k} \\
\mathrm{g})\end{array}$ & $\begin{array}{l}3.75- \\
51.02\end{array}$ & $\begin{array}{l}12.5 \\
9\end{array}$ & 8.60 & $\begin{array}{l}9.6 \\
5\end{array}$ & $\begin{array}{l}1.82- \\
25.26\end{array}$ & $\begin{array}{l}13.9 \\
5\end{array}$ & $\begin{array}{l}13.7 \\
7\end{array}$ & 4.12 & $\begin{array}{l}7.04- \\
17.11\end{array}$ & $\begin{array}{l}12.4 \\
0\end{array}$ & $\begin{array}{l}12.9 \\
2\end{array}$ & $\begin{array}{l}3.2 \\
6\end{array}$ \\
\hline $\begin{array}{l}\mathrm{Cu} \\
(\mathrm{mg} / \mathrm{k} \\
\mathrm{g})\end{array}$ & $\begin{array}{l}6.00- \\
38.01\end{array}$ & $\begin{array}{l}13.9 \\
8\end{array}$ & $\begin{array}{l}11.5 \\
5\end{array}$ & $\begin{array}{l}6.7 \\
6\end{array}$ & $\begin{array}{l}29.20- \\
61.79\end{array}$ & $\begin{array}{l}42.9 \\
7\end{array}$ & $\begin{array}{l}44.0 \\
1\end{array}$ & 7.53 & $\begin{array}{l}34.49- \\
75.00\end{array}$ & $\begin{array}{l}45.8 \\
4\end{array}$ & $\begin{array}{l}42.4 \\
9\end{array}$ & $\begin{array}{l}10 . \\
18\end{array}$ \\
\hline $\begin{array}{l}\text { Co } \\
(\mathrm{mg} / \mathrm{k} \\
\mathrm{g})\end{array}$ & $\begin{array}{l}<\quad 5.00- \\
10.29\end{array}$ & 7.36 & 5.98 & $\begin{array}{l}2.1 \\
3\end{array}$ & $\begin{array}{l}16.47- \\
239.37\end{array}$ & $\begin{array}{l}84.1 \\
5\end{array}$ & $\begin{array}{l}74.2 \\
4\end{array}$ & $\begin{array}{l}47.2 \\
1\end{array}$ & $\begin{array}{l}38.21- \\
98.89\end{array}$ & $\begin{array}{l}67.7 \\
1\end{array}$ & $\begin{array}{l}70.9 \\
5\end{array}$ & $\begin{array}{l}17 . \\
79\end{array}$ \\
\hline $\begin{array}{l}\mathrm{Ba} \\
(\mathrm{mg} / \mathrm{k} \\
\mathrm{g})\end{array}$ & $\begin{array}{l}173.61- \\
424.67\end{array}$ & $\begin{array}{l}344 . \\
09\end{array}$ & $\begin{array}{l}342 . \\
40\end{array}$ & $\begin{array}{l}53 . \\
04\end{array}$ & $\begin{array}{l}140.59- \\
487.24\end{array}$ & $\begin{array}{l}384 . \\
73\end{array}$ & $\begin{array}{l}385 . \\
71\end{array}$ & $\begin{array}{l}62.9 \\
1\end{array}$ & $\begin{array}{l}363.52- \\
467.38\end{array}$ & $\begin{array}{l}424 . \\
11\end{array}$ & $\begin{array}{l}432 . \\
68\end{array}$ & $\begin{array}{l}30 . \\
92\end{array}$ \\
\hline $\begin{array}{l}\text { Ni } \\
(\mathrm{mg} / \mathrm{k} \\
\mathrm{g})\end{array}$ & $\begin{array}{l}<10.00- \\
32.13\end{array}$ & $\begin{array}{l}15.0 \\
9\end{array}$ & $\begin{array}{l}12.7 \\
7\end{array}$ & $\begin{array}{l}5.2 \\
0\end{array}$ & $\begin{array}{l}14.42- \\
47.64\end{array}$ & $\begin{array}{l}38.8 \\
7\end{array}$ & $\begin{array}{l}40.4 \\
3\end{array}$ & 6.97 & $\begin{array}{l}24.69- \\
51.39\end{array}$ & $\begin{array}{l}34.5 \\
4\end{array}$ & $\begin{array}{l}32.1 \\
1\end{array}$ & $\begin{array}{l}7.6 \\
3\end{array}$ \\
\hline $\begin{array}{l}\text { P } \\
(\mathrm{mg} / \mathrm{k} \\
\mathrm{g})\end{array}$ & $\begin{array}{l}405.81- \\
1411.48\end{array}$ & $\begin{array}{l}799 . \\
49\end{array}$ & $\begin{array}{l}771 . \\
55\end{array}$ & $\begin{array}{l}231 \\
.09\end{array}$ & $\begin{array}{l}873.85- \\
2497.65\end{array}$ & $\begin{array}{l}107 \\
3.06\end{array}$ & $\begin{array}{l}982 . \\
99\end{array}$ & $\begin{array}{l}337 . \\
23\end{array}$ & $\begin{array}{l}1012.70- \\
1379.26\end{array}$ & $\begin{array}{l}114 \\
8.26\end{array}$ & $\begin{array}{l}113 \\
4.45\end{array}$ & $\begin{array}{l}104 \\
.67\end{array}$ \\
\hline
\end{tabular}


643

\begin{tabular}{|c|c|c|c|c|c|c|c|c|c|c|c|c|}
\hline $\begin{array}{l}\mathbf{P b} \\
(\mathrm{mg} / \mathrm{k} \\
\mathrm{g})\end{array}$ & $\begin{array}{l}<20.00- \\
34.05\end{array}$ & $\begin{array}{l}24.3 \\
1\end{array}$ & $\begin{array}{l}23.3 \\
1\end{array}$ & $\begin{array}{l}3.4 \\
5\end{array}$ & $\begin{array}{l}<20.00- \\
33.17\end{array}$ & $\begin{array}{l}24.7 \\
9\end{array}$ & $\begin{array}{l}24.7 \\
2\end{array}$ & 3.31 & $\begin{array}{l}<20.00- \\
107.06\end{array}$ & $\begin{array}{l}28.4 \\
9\end{array}$ & $\begin{array}{l}26.1 \\
2\end{array}$ & $\begin{array}{l}18 . \\
42\end{array}$ \\
\hline $\begin{array}{l}\text { Sr } \\
(\mathrm{mg} / \mathrm{k} \\
\mathrm{g})\end{array}$ & $\begin{array}{l}297.62- \\
1849.98\end{array}$ & $\begin{array}{l}126 \\
2.31\end{array}$ & $\begin{array}{l}130 \\
7.94\end{array}$ & $\begin{array}{l}282 \\
.34\end{array}$ & $\begin{array}{l}292.68- \\
622.18\end{array}$ & $\begin{array}{l}441 . \\
07\end{array}$ & $\begin{array}{l}405 . \\
73\end{array}$ & $\begin{array}{l}103 . \\
17\end{array}$ & $\begin{array}{l}315.19- \\
2453.00\end{array}$ & $\begin{array}{l}998 . \\
27\end{array}$ & $\begin{array}{l}765 . \\
39\end{array}$ & $\begin{array}{l}615 \\
.13\end{array}$ \\
\hline $\begin{array}{l}\mathbf{T i} \\
(\mathrm{mg} / \mathbf{k} \\
\mathrm{g})\end{array}$ & $\begin{array}{l}120.91- \\
1489.75\end{array}$ & $\begin{array}{l}401 . \\
62\end{array}$ & $\begin{array}{l}251 . \\
75\end{array}$ & $\begin{array}{l}317 \\
.97\end{array}$ & $\begin{array}{l}401.77- \\
8767.36\end{array}$ & $\begin{array}{l}366 \\
2.94\end{array}$ & $\begin{array}{l}337 \\
0.53\end{array}$ & $\begin{array}{l}165 \\
3.89\end{array}$ & $\begin{array}{l}1680.17- \\
4432.90\end{array}$ & $\begin{array}{l}320 \\
9.97\end{array}$ & $\begin{array}{l}348 \\
9.58\end{array}$ & $\begin{array}{l}923 \\
.80\end{array}$ \\
\hline $\begin{array}{l}\text { V } \\
(\mathrm{mg} / \mathrm{k} \\
\text { g) }\end{array}$ & $\begin{array}{l}6.15- \\
48.98\end{array}$ & $\begin{array}{l}14.2 \\
1\end{array}$ & $\begin{array}{l}10.5 \\
9\end{array}$ & $\begin{array}{l}9.2 \\
1\end{array}$ & $\begin{array}{l}19.90- \\
306.27\end{array}$ & $\begin{array}{l}107 . \\
12\end{array}$ & $\begin{array}{l}94.6 \\
3\end{array}$ & $\begin{array}{l}60.2 \\
3\end{array}$ & $\begin{array}{l}41.60- \\
115.87\end{array}$ & $\begin{array}{l}81.9 \\
4\end{array}$ & $\begin{array}{l}88.9 \\
0\end{array}$ & $\begin{array}{l}22 . \\
37\end{array}$ \\
\hline $\begin{array}{l}\mathrm{Zn} \\
(\mathrm{mg} / \mathrm{k} \\
\mathrm{g})\end{array}$ & $\begin{array}{l}14.97- \\
72.89\end{array}$ & $\begin{array}{l}29.8 \\
2\end{array}$ & $\begin{array}{l}26.4 \\
8\end{array}$ & $\begin{array}{l}13 . \\
50\end{array}$ & $\begin{array}{l}78.68- \\
115.15\end{array}$ & $\begin{array}{l}90.7 \\
1\end{array}$ & $\begin{array}{l}92.0 \\
8\end{array}$ & 8.48 & $\begin{array}{l}61.79- \\
511.83\end{array}$ & $\begin{array}{l}247 . \\
02\end{array}$ & $\begin{array}{l}223 . \\
21\end{array}$ & $\begin{array}{l}133 \\
.88\end{array}$ \\
\hline $\begin{array}{l}\mathrm{Zr} \\
(\mathrm{mg} / \mathrm{k} \\
\mathrm{g})\end{array}$ & $\begin{array}{l}10.00- \\
81.12\end{array}$ & $\begin{array}{l}26.4 \\
5\end{array}$ & $\begin{array}{l}18.0 \\
3\end{array}$ & $\begin{array}{l}17 . \\
52\end{array}$ & $\begin{array}{l}23.88- \\
185.67\end{array}$ & $\begin{array}{l}151 . \\
72\end{array}$ & $\begin{array}{l}155 . \\
65\end{array}$ & $\begin{array}{l}32.4 \\
2\end{array}$ & $\begin{array}{l}108.00- \\
205.60\end{array}$ & $\begin{array}{l}155 . \\
54\end{array}$ & $\begin{array}{l}157 . \\
97\end{array}$ & $\begin{array}{l}32 . \\
28\end{array}$ \\
\hline
\end{tabular}

644

Table 4. Descriptive statistics of $I_{g e o}$ values in all studied lagoons.

\begin{tabular}{lllllllll}
\hline & & \multicolumn{7}{c}{$\mathbf{I}_{\text {geo }}$} \\
\cline { 3 - 8 } & & $\mathbf{C r}$ & $\mathbf{C o}$ & $\mathbf{C u}$ & $\mathbf{N i}$ & $\mathbf{P b}$ & $\mathbf{V}$ & $\mathbf{Z n}$ \\
\hline \multirow{3}{*}{ Amirkola (n=56) } & Min & -5.20 & -2.17 & -2.81 & -2.80 & -0.32 & -4.56 & -2.75 \\
& Max & -1.44 & -1.34 & -0.14 & -1.13 & 0.42 & -1.57 & -0.46 \\
& Mean & $\mathbf{- 3 . 7 5}$ & $\mathbf{- 1 . 8 6}$ & $\mathbf{- 1 . 7 2}$ & $\mathbf{- 2 . 2 9}$ & $\mathbf{- 0 . 0 8}$ & $\mathbf{- 3 . 5 6}$ & $\mathbf{- 1 . 8 8}$ \\
& Median & -4.00 & -2.12 & -1.86 & -2.47 & -0.13 & -3.78 & -1.92 \\
& SD & 0.88 & 0.40 & 0.60 & 0.43 & 0.19 & 0.73 & 0.59 \\
\hline & Min & -6.25 & -0.66 & -0.52 & -2.29 & -0.77 & -2.87 & -0.35 \\
Zibakenar (n=22) & Max & -2.45 & 3.21 & 0.56 & -0.57 & 0.38 & 1.07 & 0.20 \\
& Mean & $\mathbf{- 3 . 4 1}$ & $\mathbf{1 . 5 4}$ & $\mathbf{0 . 0 1}$ & $\mathbf{- 0 . 8 9}$ & $\mathbf{- 0 . 0 5}$ & $\mathbf{- 0 . 6 0}$ & $\mathbf{- 0 . 1 5}$ \\
& Median & -3.33 & 1.52 & 0.07 & -0.80 & -0.04 & -0.62 & -0.13 \\
& SD & 0.68 & 0.69 & 0.25 & 0.35 & 0.21 & 0.70 & 0.13 \\
\hline \multirow{5}{*}{ Kiashahr (n=28) } & Min & -4.29 & 0.56 & -0.28 & -1.51 & -0.77 & -1.81 & -0.70 \\
& Max & -3.01 & 1.93 & 0.84 & -0.46 & 2.07 & -0.33 & 2.35 \\
& Mean & $\mathbf{- 3 . 5 6}$ & $\mathbf{1 . 3 0}$ & $\mathbf{0 . 1 1}$ & $\mathbf{- 1 . 0 5}$ & $\mathbf{- 0 . 0 1}$ & $\mathbf{- 0 . 9 3}$ & $\mathbf{0 . 9 6}$ \\
& Median & -3.46 & 1.33 & 0.09 & -1.12 & -0.06 & -0.82 & 0.99 \\
& SD & 0.43 & 0.43 & 0.31 & 0.33 & 0.62 & 0.47 & 0.96 \\
\hline
\end{tabular}

645

646

647

648

649

650

651

652 
653 Table 5. Descriptive statistics of CF and PLI values of studied metals in all three lagoons.

PLI values of each lagoon are presented in this table.

\begin{tabular}{|c|c|c|c|c|c|c|c|c|c|c|}
\hline & & \multicolumn{7}{|c|}{ CF } & \multirow{2}{*}{ PLI } & \multirow{2}{*}{ PLI (Lagoon } \\
\hline & & $\mathrm{Cr}$ & Co & $\mathbf{C u}$ & $\mathbf{N i}$ & $\mathbf{P b}$ & $\mathbf{V}$ & $\mathbf{Z n}$ & & \\
\hline \multirow{5}{*}{ Amirkola $(n=56)$} & Min & 0.04 & 0.33 & 0.21 & 0.22 & 1.20 & 0.06 & 0.22 & 0.12 & \multirow{5}{*}{0.24} \\
\hline & Max & 0.55 & 0.59 & 1.36 & 0.68 & 2.00 & 0.50 & 1.09 & 0.68 & \\
\hline & Mean & 0.14 & 0.43 & 0.50 & 0.32 & 1.43 & 0.15 & 0.45 & 0.27 & \\
\hline & Median & 0.09 & 0.35 & 0.41 & 0.27 & 1.37 & 0.11 & 0.40 & 0.24 & \\
\hline & SD & 0.10 & 0.12 & 0.24 & 0.11 & 0.20 & 0.09 & 0.20 & 0.14 & \\
\hline \multirow{5}{*}{ Zibakenar $(n=22)$} & Min & 0.02 & 0.95 & 1.04 & 0.31 & 0.88 & 0.21 & 1.17 & 0.43 & \multirow{5}{*}{1.05} \\
\hline & Max & 0.27 & 13.84 & 2.21 & 1.01 & 1.95 & 3.16 & 1.72 & 1.65 & \\
\hline & Mean & 0.15 & 4.86 & 1.53 & 0.83 & 1.46 & 1.10 & 1.35 & 1.08 & \\
\hline & Median & 0.15 & 4.29 & 1.57 & 0.86 & 1.45 & 0.98 & 1.37 & 1.07 & \\
\hline & SD & 0.04 & 2.73 & 0.27 & 0.15 & 0.19 & 0.62 & 0.13 & 0.21 & \\
\hline \multirow{5}{*}{ Kiashahr $(\mathrm{n}=28)$} & Min & 0.08 & 2.21 & 1.23 & 0.53 & 0.88 & 0.43 & 0.92 & 0.71 & \multirow{5}{*}{1.12} \\
\hline & Max & 0.19 & 5.72 & 2.68 & 1.09 & 6.30 & 1.19 & 7.64 & 1.70 & \\
\hline & Mean & 0.13 & 3.92 & 1.63 & 0.74 & 1.63 & 0.84 & 3.83 & 1.15 & \\
\hline & Median & 0.14 & 4.10 & 1.58 & 0.69 & 1.49 & 0.92 & 3.42 & 1.23 & \\
\hline & SD & 0.04 & 1.05 & 0.35 & 0.17 & 1.01 & 0.24 & 2.05 & 0.18 & \\
\hline
\end{tabular}

655

656

657

658

659

660

661

662

663

664

665

666

667

668

669 
670 Table 6. Pearson's correlation coefficients of some studied elements in all three lagoons.

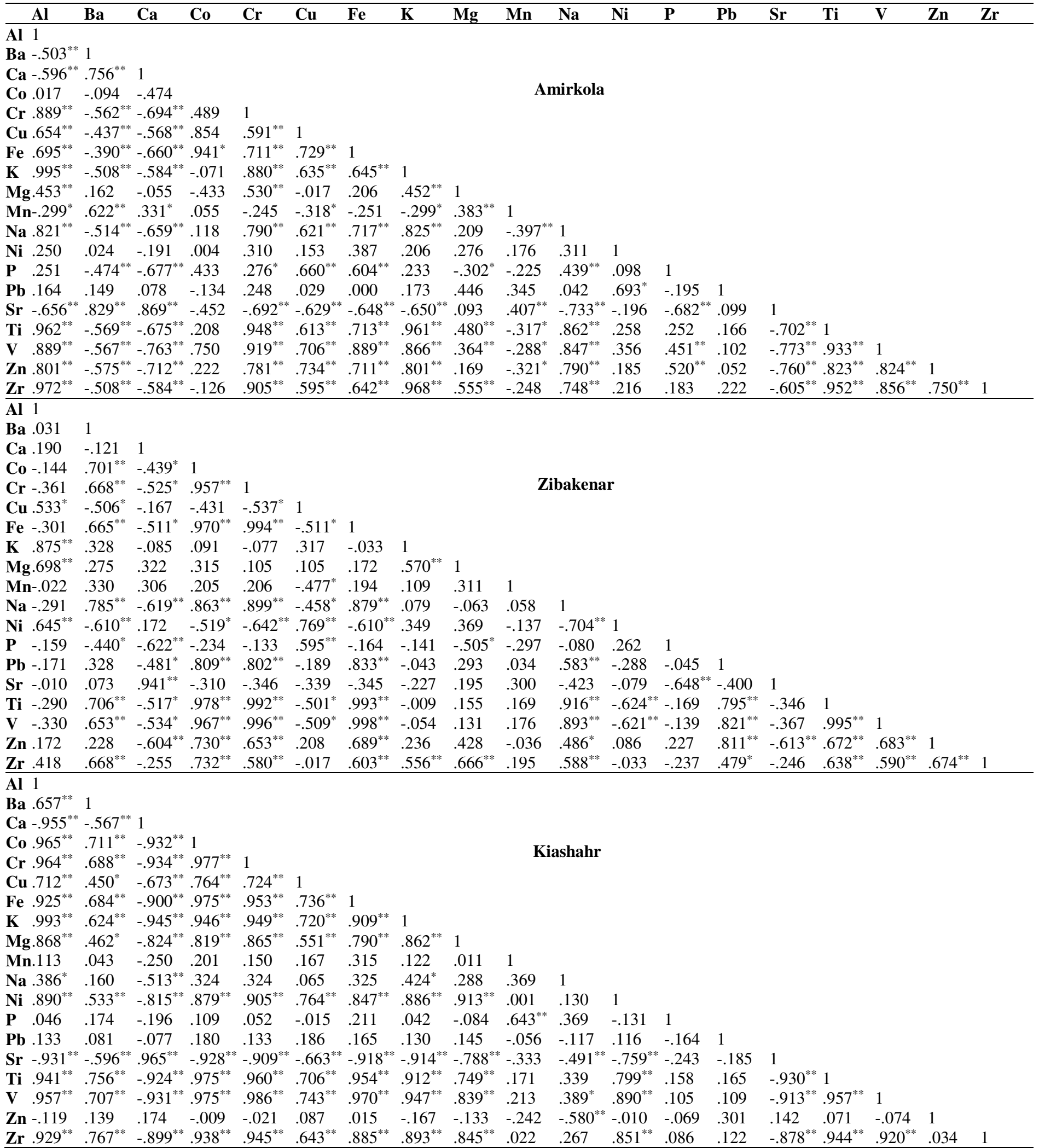


Table 7. Models' residual values normality test.

One-Sample Kolmogorov-Smirnov Test

Standardized Residual

\begin{tabular}{lccccccccccc}
\hline & $\mathbf{A l}$ & $\mathbf{C o}$ & $\mathbf{C r}$ & $\mathbf{C u}$ & $\mathbf{F e}$ & $\mathbf{N i}$ & $\mathbf{P b}$ & $\mathbf{T i}$ & $\mathbf{V}$ & $\mathbf{Z n}$ & $\mathbf{Z r}$ \\
Test Statistic & 0.141 & 0.106 & 0.184 & 0.118 & 0.173 & 0.119 & 0.275 & 0.156 & 0.198 & 0.271 & 0.123 \\
Asymp. Sig. (2-tailed) & 0.000 & $\mathbf{0 . 1 8 8}$ & 0.000 & 0.001 & 0.000 & 0.012 & 0.000 & 0.000 & 0.000 & 0.000 & 0.000 \\
\hline 6
\end{tabular}

676 Table 8. Nonparametric equivalent analysis of variance (Kruskal-Wallis test) (1: Amirkola 677

Lagoon; 2: Zibakenar Lagoon; 3: Kiashahr Lagoon).

\begin{tabular}{|c|c|c|c|c|c|}
\hline \multicolumn{4}{|c|}{ Ranks } & \multicolumn{2}{|c|}{ Test Statistics } \\
\hline Metal & Lagoon & $\mathrm{N}$ & Mean Rank & Chi-Square & Asymp. Sig. \\
\hline \multirow{3}{*}{$\mathrm{Al}$} & 1 & 57 & 29.00 & \multirow{3}{*}{79.697} & \multirow{3}{*}{0.000} \\
\hline & 2 & 22 & 87.95 & & \\
\hline & 3 & 28 & 77.54 & & \\
\hline \multirow{3}{*}{ Co } & 1 & 5 & 6.10 & \multirow{3}{*}{11.904} & \multirow{3}{*}{0.003} \\
\hline & 2 & 22 & 33.07 & & \\
\hline & 3 & 28 & 27.14 & & \\
\hline \multirow{3}{*}{$\mathrm{Cr}$} & 1 & 57 & 29.19 & \multirow{3}{*}{77.395} & \multirow{3}{*}{0.000} \\
\hline & 2 & 22 & 84.60 & & \\
\hline & 3 & 28 & 79.66 & & \\
\hline \multirow{3}{*}{$\mathrm{Cu}$} & 1 & 57 & 29.32 & \multirow{3}{*}{76.591} & \multirow{3}{*}{0.000} \\
\hline & 2 & 22 & 78.93 & & \\
\hline & 3 & 28 & 83.66 & & \\
\hline \multirow{3}{*}{$\mathrm{Fe}$} & 1 & 57 & 30.16 & \multirow{3}{*}{71.092} & \multirow{3}{*}{0.000} \\
\hline & 2 & 22 & 80.93 & & \\
\hline & 3 & 28 & 80.45 & & \\
\hline \multirow{3}{*}{$\mathrm{Ni}$} & 1 & 24 & 13.08 & \multirow{3}{*}{48.711} & \multirow{3}{*}{0.000} \\
\hline & 2 & 22 & 55.05 & & \\
\hline & 3 & 28 & 43.96 & & \\
\hline \multirow{3}{*}{$\mathrm{Pb}$} & 1 & 17 & 29.00 & \multirow{3}{*}{1.409} & \multirow{3}{*}{0.494} \\
\hline & 2 & 22 & 36.29 & & \\
\hline & 3 & 28 & 34.14 & & \\
\hline \multirow{3}{*}{$\mathrm{Ti}$} & 1 & 57 & 29.00 & \multirow{3}{*}{78.320} & \multirow{3}{*}{0.000} \\
\hline & 2 & 22 & 82.43 & & \\
\hline & 3 & 28 & 81.68 & & \\
\hline \multirow{3}{*}{$\mathrm{V}$} & 1 & 57 & 29.09 & \multirow{3}{*}{78.635} & \multirow{3}{*}{0.000} \\
\hline & 2 & 22 & 86.67 & & \\
\hline & 3 & 28 & 78.32 & & \\
\hline & 1 & 57 & 29.09 & & \\
\hline $\mathrm{Zn}$ & 2 & 22 & 72.02 & 81.543 & 0.000 \\
\hline & 3 & 28 & 89.30 & & \\
\hline $7 r$ & 1 & 57 & 29.00 & 78321 & مOQ \\
\hline $\mathrm{Zr}$ & 2 & 22 & 81.57 & 18.321 & 0.000 \\
\hline
\end{tabular}


679 Table 9. Independent sample t-test results. (1: Amirkola Lagoon; 2: Zibakenar Lagoon; 3:

Kiashahr Lagoon)

\begin{tabular}{|c|c|c|c|c|c|c|c|c|c|c|c|}
\hline \multicolumn{12}{|c|}{$1-2$} \\
\hline & $\mathrm{Al}$ & $\mathrm{Co}$ & $\mathrm{Cr}$ & $\mathrm{Cu}$ & $\mathrm{Fe}$ & $\mathrm{Ni}$ & $\mathrm{Pb}$ & $\mathrm{Ti}$ & V & $\mathrm{Zn}$ & $\mathrm{Zr}$ \\
\hline$Z$ & -6.743 & -3.418 & -6.743 & -6.630 & -6.517 & -5.711 & -1.542 & -6.743 & -6.742 & -6.742 & -6.742 \\
\hline $\begin{array}{l}\text { Asymp.Sig. } \\
(2-\text { tailed })\end{array}$ & .000 & .001 & .000 & .000 & .000 & .000 & .123 & .000 & .000 & .000 & .000 \\
\hline Bonferonni $p$ & 0.000 & 0.003 & .000 & .000 & .000 & .000 & 0.369 & .000 & .000 & .000 & .000 \\
\hline \multicolumn{12}{|c|}{$1-3$} \\
\hline $\mathrm{Z}$ & -7.463 & -2.737 & -7.359 & -7.387 & -7.032 & -5.929 & -.562 & -7.462 & -7.415 & -7.415 & -7.462 \\
\hline $\begin{array}{c}\text { Asymp. Sig. } \\
\text { (2-tailed) }\end{array}$ & .000 & .006 & .000 & .000 & .000 & .000 & .574 & .000 & .000 & .000 & .000 \\
\hline Bonferonni $p$ & .000 & 0.012 & .000 & .000 & .000 & .000 & 1 & .000 & .000 & .000 & .000 \\
\hline \multicolumn{12}{|c|}{$2-3$} \\
\hline $\mathrm{Z}$ & -2.525 & -1.303 & -1.101 & -1.101 & -.051 & -2.586 & -.121 & -.182 & -1.980 & -4.233 & -.182 \\
\hline $\begin{array}{c}\text { Asymp. Sig. } \\
\text { (2-tailed) }\end{array}$ & .012 & .192 & .271 & .271 & .960 & .010 & .903 & .856 & .048 & .000 & .856 \\
\hline Bonferonni $p$ & 0.036 & 0.576 & 0.813 & 0.813 & 1 & 0.03 & 1 & 0.285 & 0.144 & 0.000 & 1 \\
\hline
\end{tabular}

681

682

683

684 

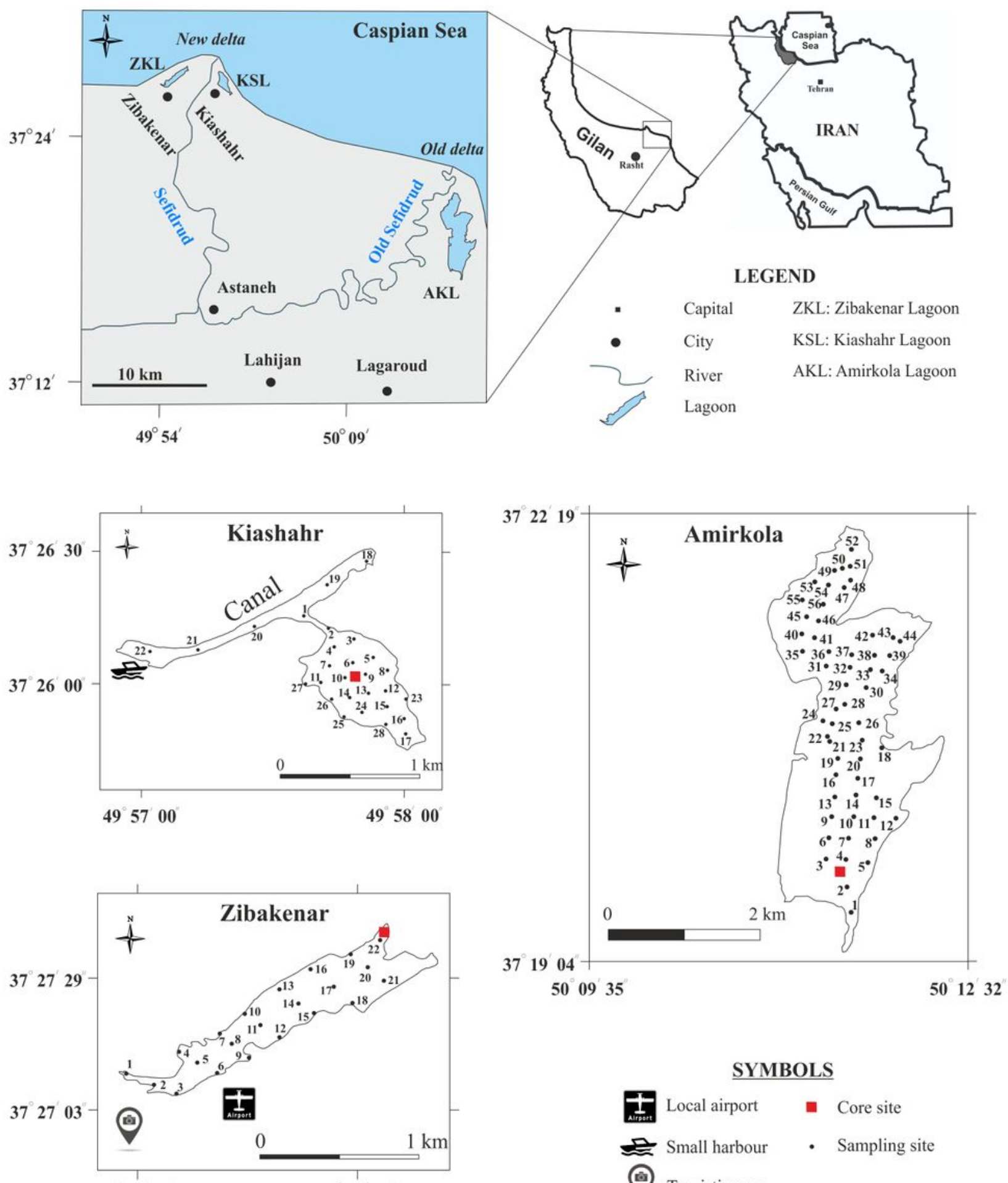

495248

495342

\section{$\underline{\text { SYMBOLS }}$}

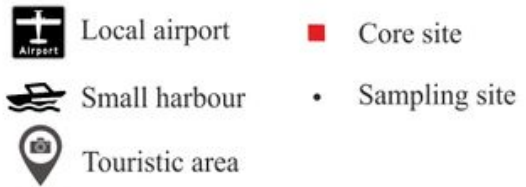

\section{Figure 1}

Location map and sampling points of the studied lagoons. (ZKL: Zibakenar Lagoon; KSL: Kiashahr Lagoon; AKL: Amirkola Lagoon). Red squares indicate the core sample location in each lagoon. 


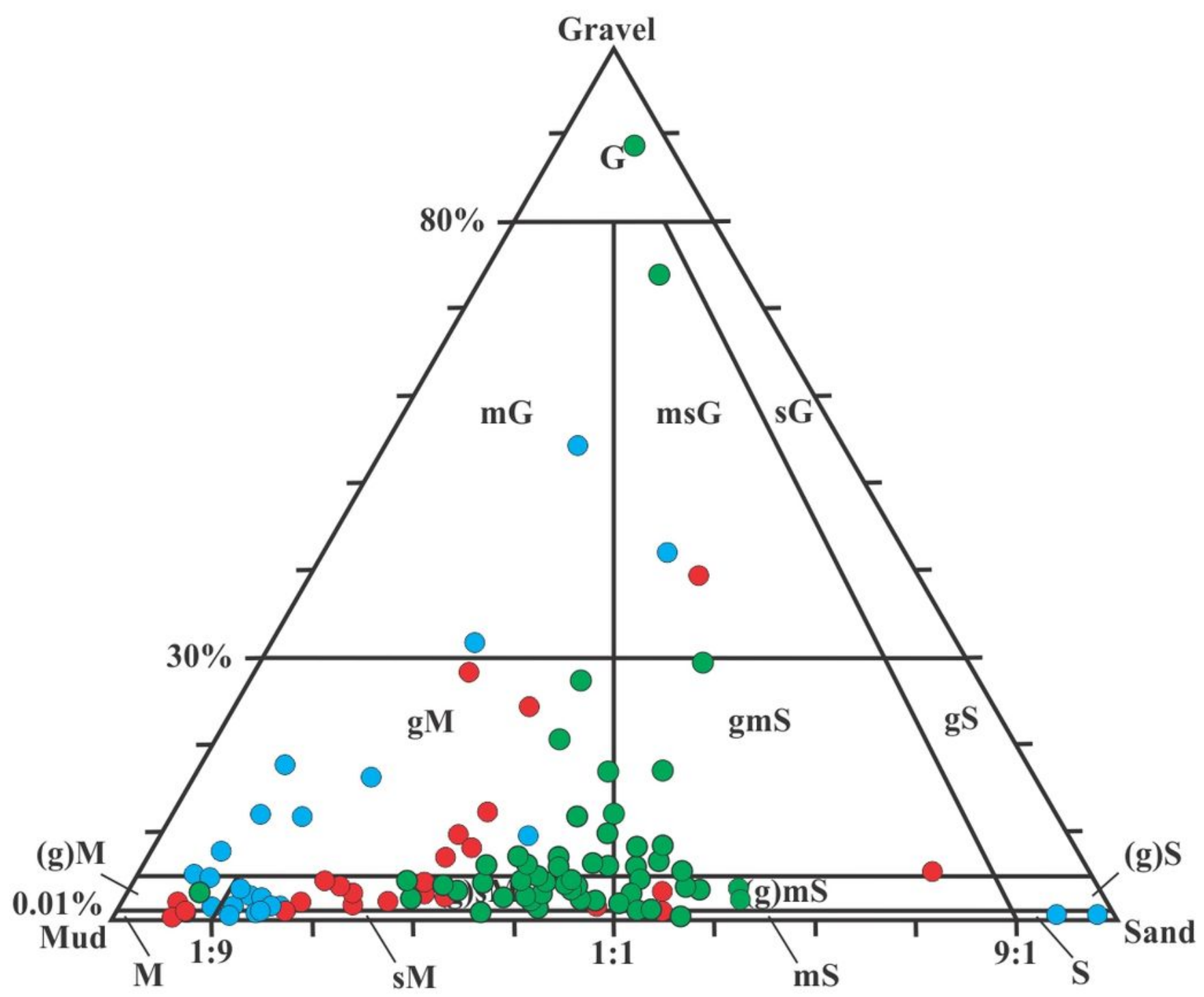

G: gravel; g: gravelly; (g): slightly gravelly

S: sand; s: sandy

M: mud; m: muddy

- Amirkola

- Zibakenar

- Kiashahr

Figure 2

Textural classification of studied samples in three lagoons based on Folk (1980). (Black circles: Zibakenar samples; Red circles: Kiashahr samples; Yellow circles: Amirkola samples) 


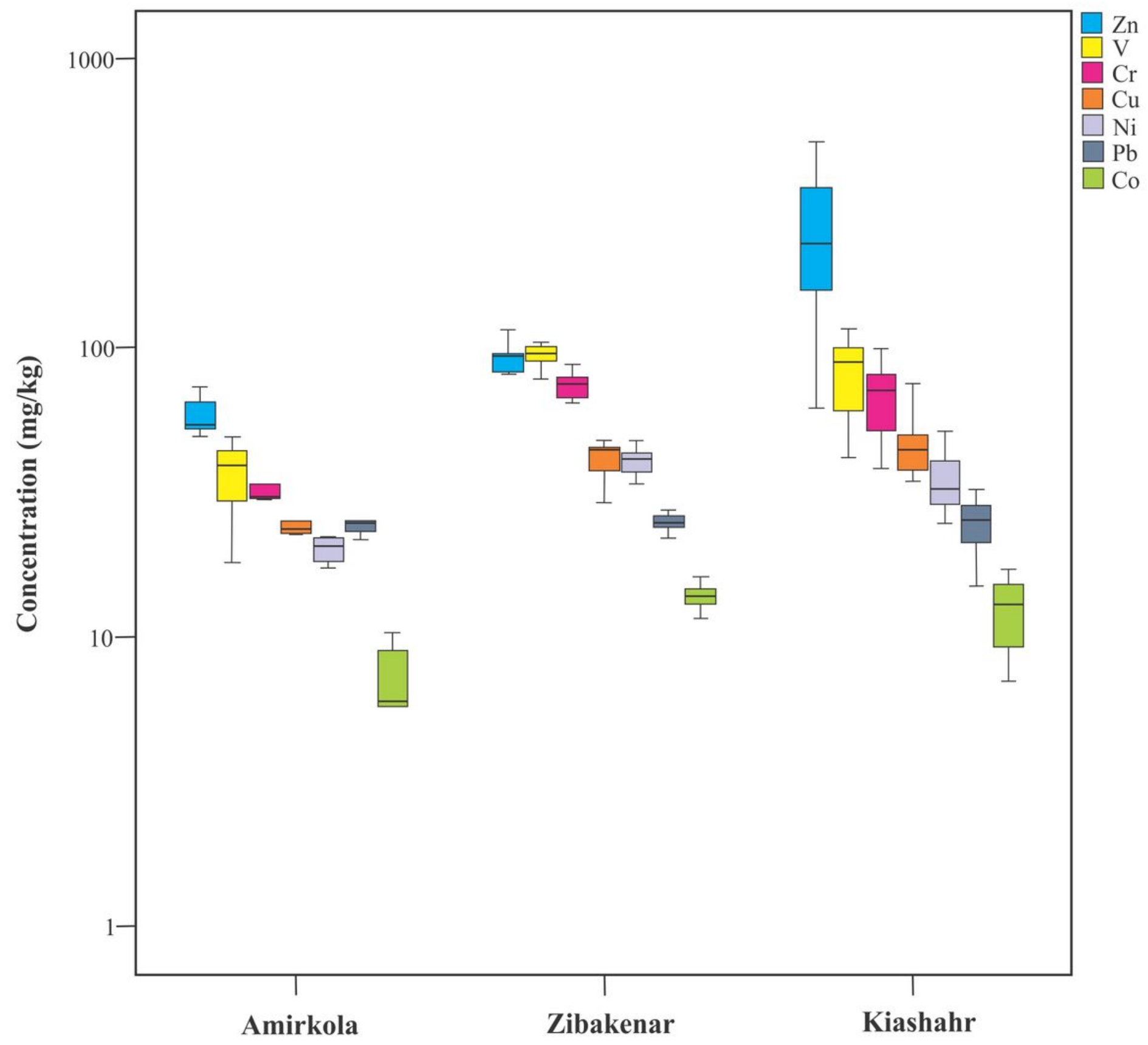

Figure 3

Box plot diagram of metal concentrations in studied lagoons. 

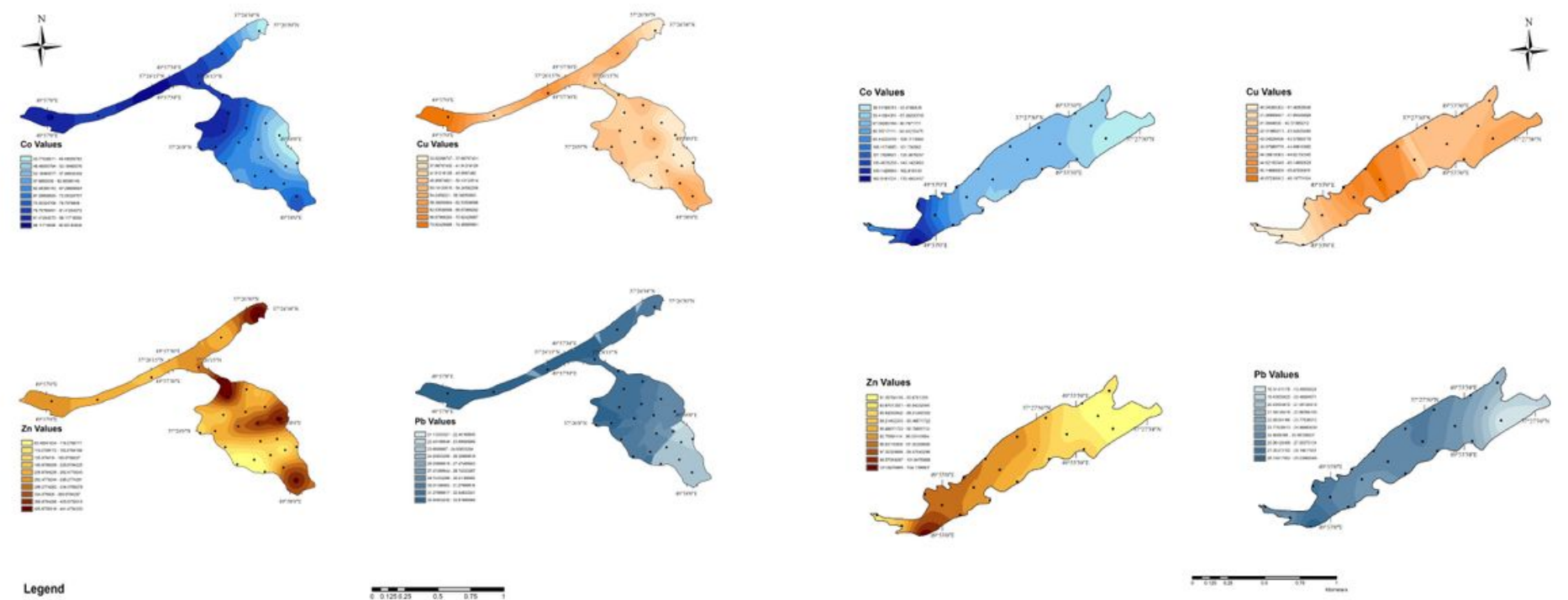

Logend

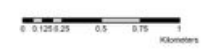

Figure 4

Distribution map of some studied metals in the Zibakenar and Kiashahr lagoons. 

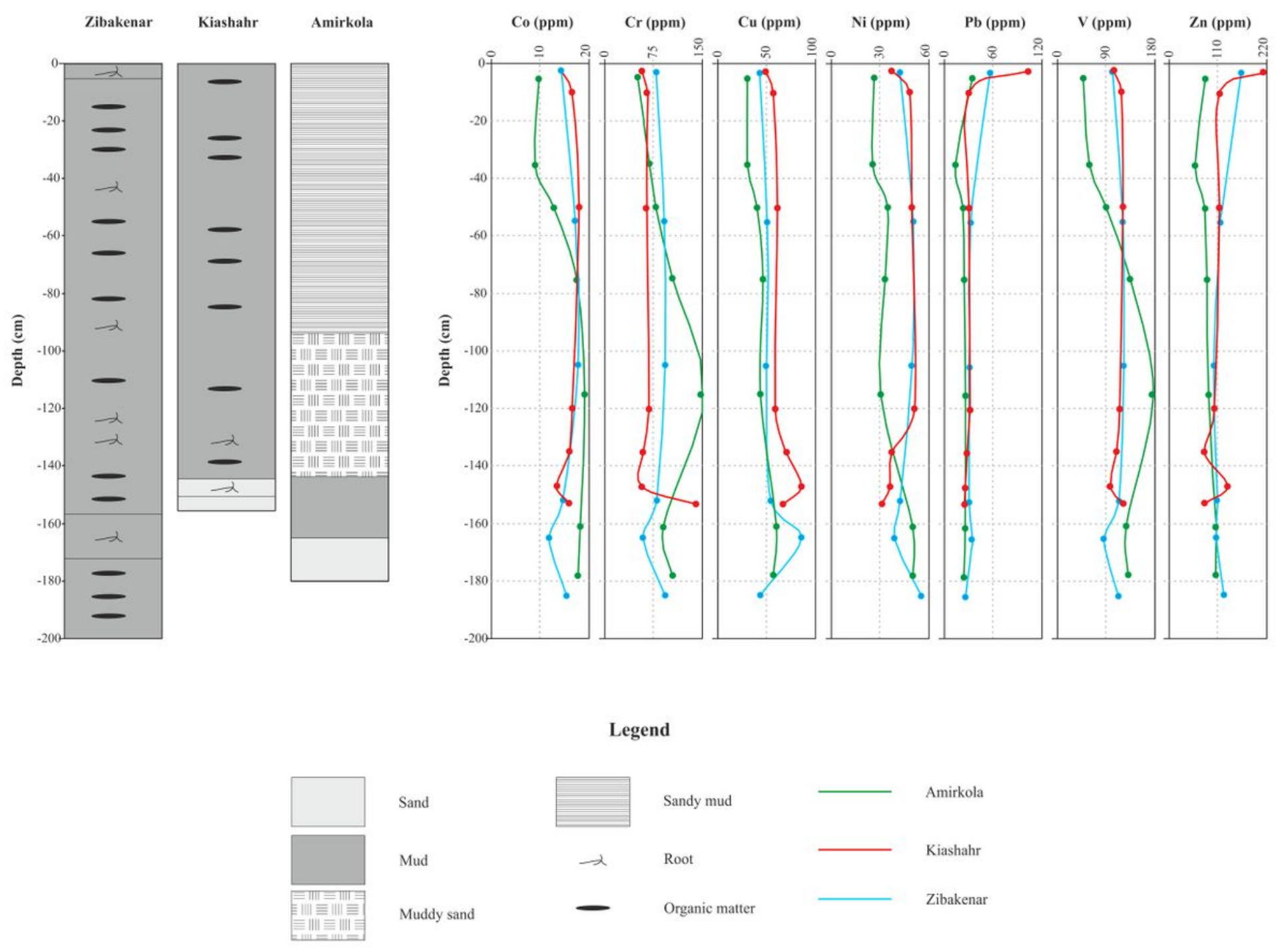

Figure 5

Sedimentary facies and heavy metals concentrations changes in core samples taken from studied lagoons. The Amirkola Lagoon sediments are temporally different from the others. 


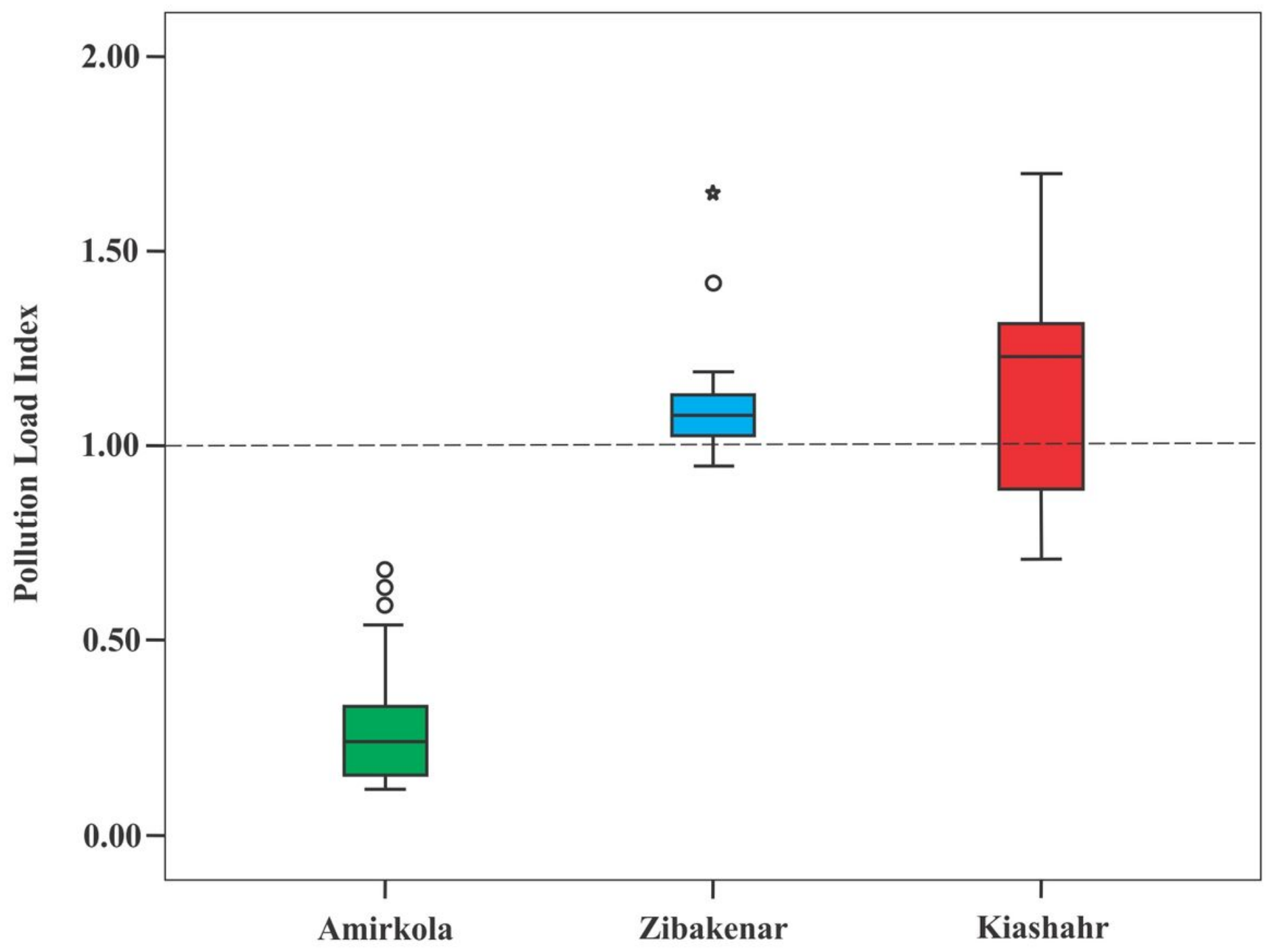

Figure 6

Box Plot diagram of PLI values in all three lagoons. 


\section{Cluster Sizes}

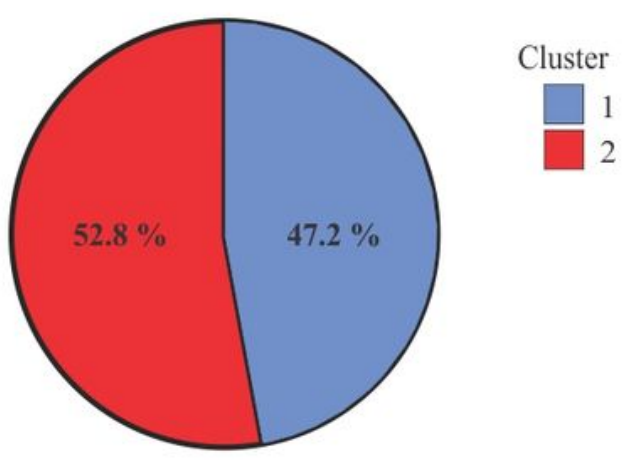

(a)

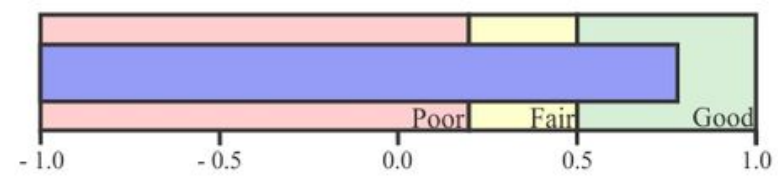

Silhouette measure of cohesion and separation

\begin{tabular}{|l|l|}
\hline Size of smallest cluster & $50(47.2 \%)$ \\
\hline Size of largest cluster & $56(52.8 \%)$ \\
\hline $\begin{array}{l}\text { Ratio of sizes: } \\
\text { Largest cluster to } \\
\text { Smallest cluster }\end{array}$ & 1.12 \\
\hline
\end{tabular}

\begin{tabular}{|l|l|}
\multicolumn{2}{c}{ Model Summary } \\
\hline Algorithm & TwoStep \\
\hline Inputs & 8 \\
\hline Clusters & 2 \\
\hline
\end{tabular}

Predictor Importance

(b)

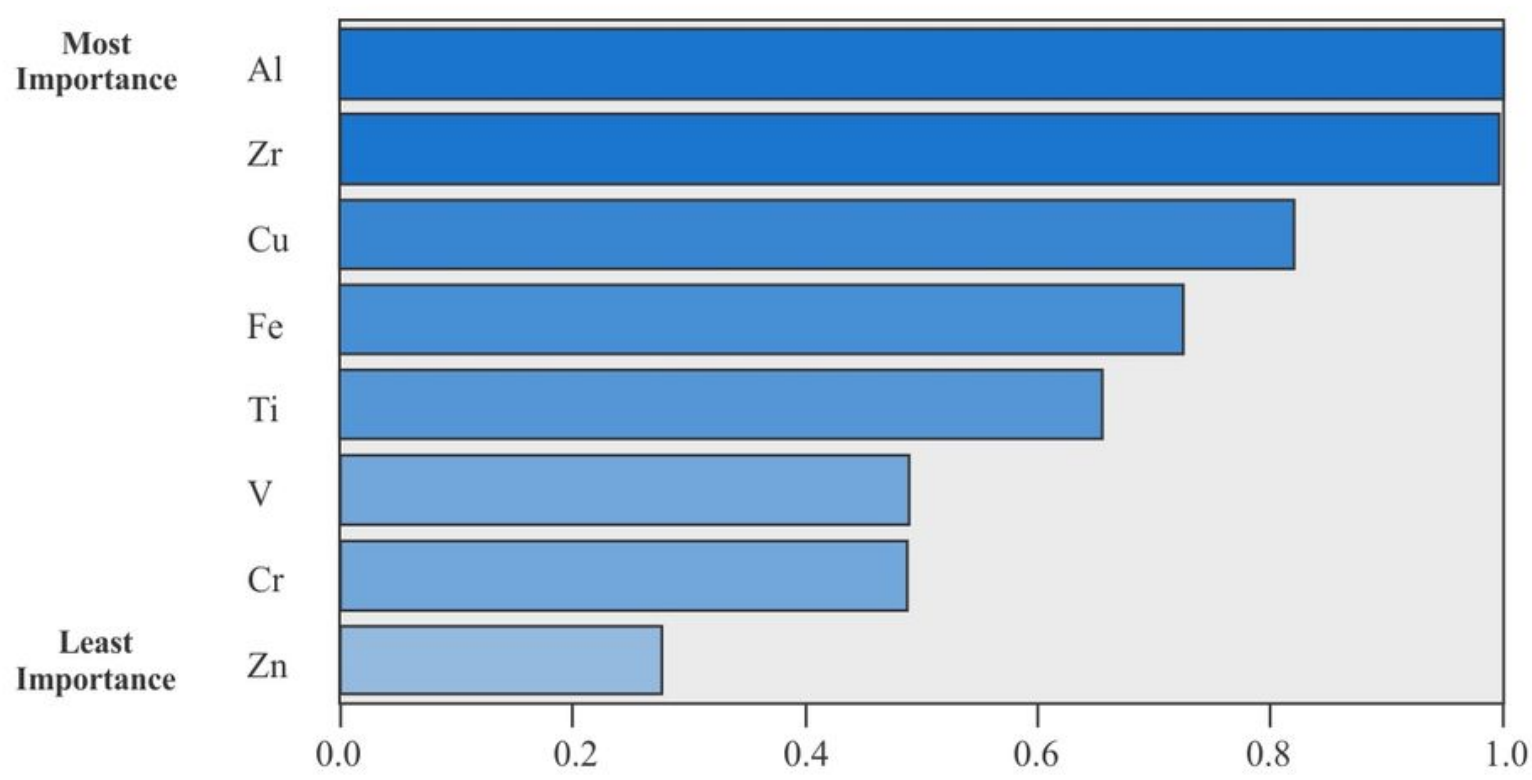

\section{Figure 7}

Results of two-step cluster analysis, a) Silhouette measure shows values close to the maximum amount, and cluster sizes including two distinct clusters; $b$ ) features from the most to the least predictor (variable) importance. 